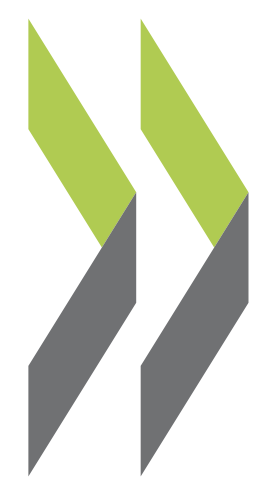

OECD Economics Department Working Papers No. 398

Product Market Competition Hannes Suppanz, and Economic Performance in the United States Michael Wise, Michael Kiley 
Organisation de Coopération et de Développement Economiques

Organisation for Economic Co-operation and Development

15-Jul-2004

ECONOMICS DEPARTMENT

English - Or. English

PRODUCT MARKET COMPETITION AND ECONOMIC PERFORMANCE

IN THE UNITED STATES

ECONOMICS DEPARTMENT WORKING PAPERS No. 398

By

Hannes Suppanz, Michael Wise and Michael Kiley

All Economics Department Working Papers are now available through OECD's Internet Web site at http:Ilwww.oecd.org/eco 


\section{ABSTRACT/RÉSUMÉ \\ Product market competition and economic performance in the United States}

Regulatory reform efforts in a broad range of industries have resulted in increased importance of competitive forces as a means to allocate resources and improve economic efficiency. A number of indicators suggest that such forces have been stronger in the United States than in most other OECD countries for some time. This has contributed to sizeable productivity gains and good economic performance over the past decade or so. Nonetheless, despite the generally pro-competitive thrust of policies, a number of challenges remain. Although there are few sectors of the economy from which competition policy and law are completely excluded, given the high risk of sanctions and damages for violation, many anomalous exemptions and special regimes have found their way into US legislation. Contrary to other OECD countries, government related firms are exempted from competition enforcement. Intellectual property rights create special challenges for competition policy and some problems have followed their strengthening over the past two decades, such as the soaring cost of patent litigation. The generally favourable experience with deregulation created pressures for liberalisation in network industries, where the United States has rather been a laggard, at least in the electricity sector. Reforms in the 1990s have entailed some positive results but also some setbacks, reflecting both the difficulties in ensuring competition in such industries and policy mistakes.

JEL classification: H57, K13, K21, K23, L4, L5, L94, L96, L98, O31, O34, O38, O4, O51

Keywords: United States, productivity and growth, product market competition, competition law, regulatory reform, intellectual property rights, network industries, public procurement, tort reform

\section{Concurrence sur les marchés de produits et performance économique aux États-Unis}

La réforme des réglementations régissant un large éventail de secteurs d'activité a permis de laisser plus largement intervenir les forces de la concurrence dans l'affectation des ressources et l'amélioration de l'efficience économique. Si l'on en croit un certain nombre d'indicateurs, ces forces ont été pendant un certain temps plus importantes aux États-Unis que dans la plupart des autres pays de l'OCDE. Elles ont ainsi rendu possible une nette amélioration de la productivité et de bons résultats économiques depuis environ une décennie. Néanmoins, bien que l'action des pouvoirs publics favorise généralement le jeu de la concurrence, un certain nombre de problèmes subsistent. Rares sont les secteurs de l'économie d'où la politique et le droit de la concurrence soient totalement exclus, étant donné le risque élevé de sanctions et de dommages-intérêts en cas de violation, mais la législation des États-Unis prévoit bon nombre d'exemptions anormales et de régimes spéciaux. A la différence des autres pays de l'OCDE, les entreprises liées au secteur public ne sont pas tenues de respecter les règles de la concurrence. Les droits de propriété intellectuelle posent des défis particuliers à la politique de la concurrence, et certains problèmes sont apparus à la suite de leur renforcement ces vingt dernières années, notamment une forte hausse du coût des litiges en matière de brevets. Les résultats généralement satisfaisants de la déréglementation ont fait naître des pressions en vue d'obtenir la libéralisation des industries de réseau, secteur dans lequel les États-Unis sont plutôt à la traîne, du moins en ce qui concerne l'électricité. Les réformes opérées dans les années 90 ont produit certains résultats positifs mais ont connu aussi quelques échecs, la faute en incombant tout à la fois à la difficulté d'assurer la concurrence dans ce type de secteur et à des erreurs des autorités.

Classification JEL : H57, K13, L21, K23, L4, L5, L94, L96, L98, O31, O34, O38, O4, O51

Mots clés: États-Unis, productivité et croissance, concurrence sur les marchés de produits, droit de la concurrence, réforme de la réglementation, droits de propriété intellectuelle, industries de réseau, marchés publics, réforme de la responsabilité civile

\section{Copyright $\odot$ OECD 2004. All rights reserved.}

Applications for permission to reproduce or translate all, or part of, this material should be made to: Head of Publications Service, OECD, 2 rue André-Pascal, 75775 PARIS CEDEX 16, France 


\section{TABLE OF CONTENTS}

Product market competition and economic performance in the United States ........................................... 5

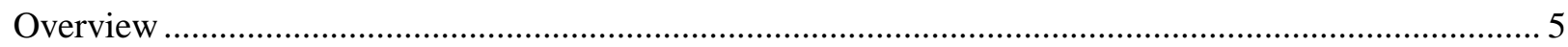

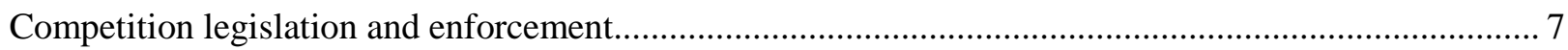

Strong competitive forces have contributed to good economic performance ........................................ 10

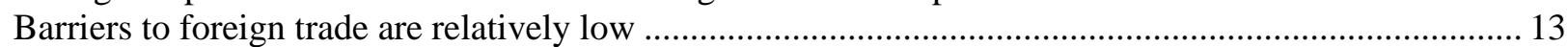

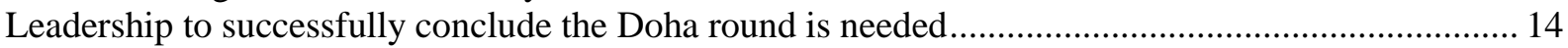

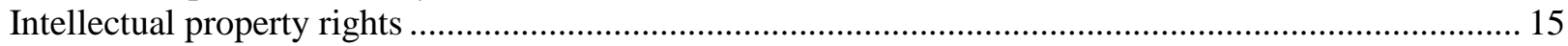

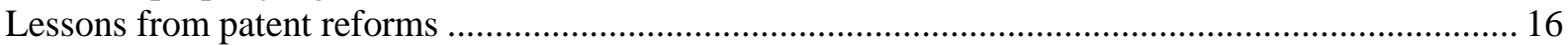

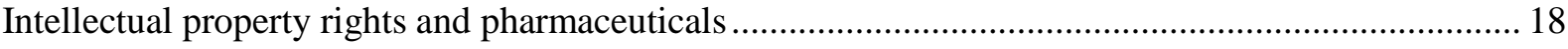

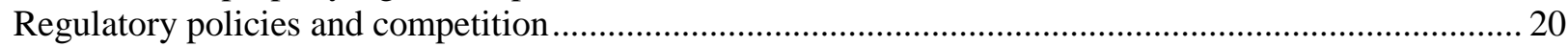

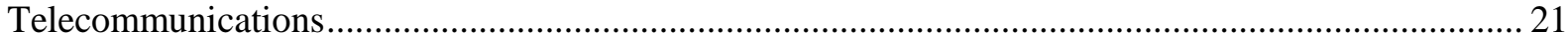

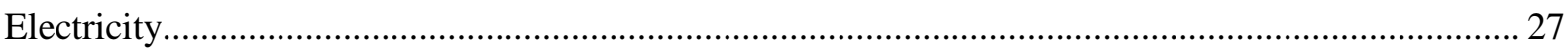

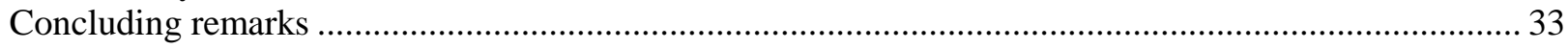

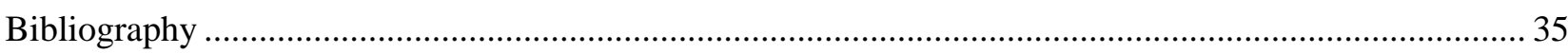

Annxes

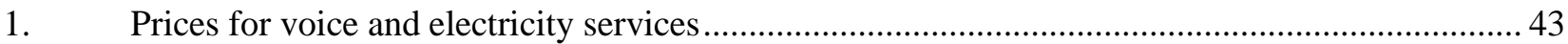

2. California's experience with reform of retail electricity markets ..................................................45

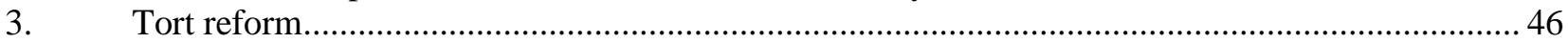

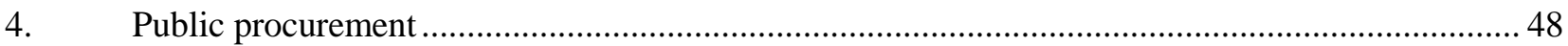

\section{Box}

1. Recommendations regarding product market competition ...................................................... 33

\section{Tables}

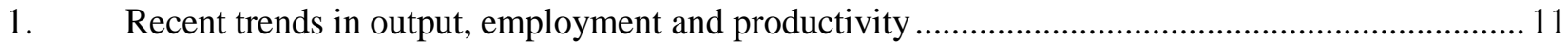

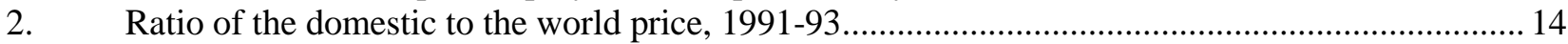

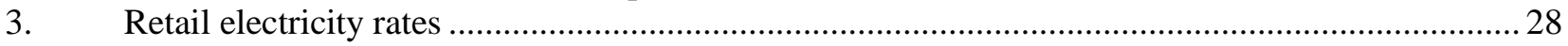

\section{Figures}

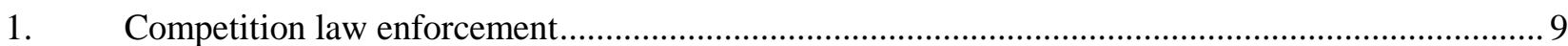

2. Indices of regulations affecting product market competition .................................................. 12

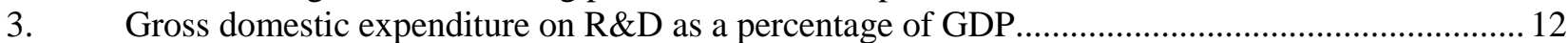

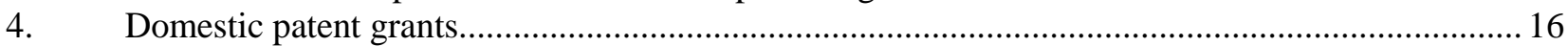

5. Market shares and prices in long-distance telephone services...................................................... 22

6. Number of competitive local exchange carriers across the United States ..................................... 24

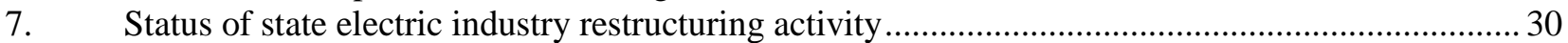

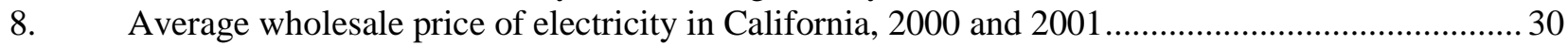


ECO/WKP(2004)21

Annexes

1. OECD composite basket of residential telephone charges ............................................................ 43

2. OECD composite basket of business telephone charges .............................................................4 43

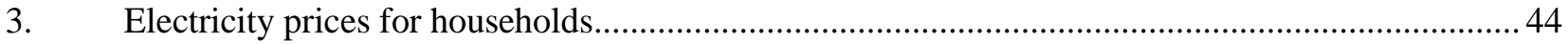


ECO/WKP(2004)21

\title{
PRODUCT MARKET COMPETITION AND ECONOMIC PERFORMANCE
}

\author{
IN THE UNITED STATES
}

by

\author{
Hannes Suppanz, Michael Wise and Michael Kiley ${ }^{1}$
}

\section{Overview}

The state of product market competition in the United States has changed significantly over the past several decades, reflecting several concurrent developments. Antitrust policy has moved beyond strict reliance on market concentration measures, designed to broadly link industry structure to conduct and performance, to adopt a more nuanced approach using modern industrial organisation analysis. Regulatory reform efforts in a broad range of industries began in the 1970s and accelerated over the course of the 1980 s, resulting in (partial) deregulation in many sectors and an increased reliance on competitive forces as a means to improve efficiency. With a view to boosting incentives for innovation, intellectual property rights were strengthened by a series of court decisions in the 1980s and 1990s, increasing the short-run market power of firms developing new products; this has raised the question of how to balance the long-run benefits from the dynamic process of creative destruction against the short-run losses in efficiency arising from innovators' temporary monopoly positions. The growing importance of knowledge-based industries (e.g. pharmaceuticals and semiconductors) and network industries (e.g. telecommunications services including the Internet and software) has interacted with these other developments to raise new challenges for efforts to ensure dynamic efficiency. And, last but not least, the increased integration of the global economy has exerted greater pressure for efficiency through foreign competition. The aim of this chapter is to assess the role that policies that bear on product market competition have played in the performance of the US economy and to recommend changes in areas where further improvements are possible.

The institutional framework governing competition legislation and enforcement is the focus of the first section. As the basic legislation has not changed for decades, antitrust policy has evolved through the interaction of academic analysis, court decisions and agency guidance. In terms of sanctions imposed, enforcement appears unusually energetic, and private litigation is also extraordinarily important. The high risks of sanction and damages for violation have encouraged claims for, and sometimes entailed, exemptions, special treatment or anti-competitive state regulation; these should be removed in the areas where they exist. Another anomaly that ought to be corrected is the partial exemption of non-profit enterprises and government-related firms from competition enforcement.

1. The authors are, or were, at the time of writing, staff at the OECD. This paper draws on material originally produced for the OECD Economic Survey of the United States published in May 2004 under the authority of the Economic and Development Review Committee. The authors are indebted to colleagues in the Economics Department of the OECD for comments and drafting suggestions, in particular Peter Jarrett, Mike Feiner, Jørgen Elmeskov, Val Koromzay and Andrew Dean. Special thanks go to Françoise Correia and Mee-Lan Frank for technical assistance. 
The following two sections step back from the institutional details ${ }^{2}$ and discuss economic performance over the past decade, and more especially the contribution to growth of policies promoting competition, both from the internal market and foreign sector. Indicators of the extent of barriers to trade and of administrative and economic regulations highlight the pro-competitive orientation of economic policies, and such conditions have spurred gains in productivity, investment and innovation. Most of the economy is also open to competition from foreign producers through international trade, resulting in low prices (relative to other Member countries) and hence higher consumer welfare. Nonetheless, there are some serious barriers to such competition, and policy initiatives that lessen reliance on anti-dumping or safeguard actions (such as the softwood lumber and steel cases should be pursued.

Moreover, an international price comparison reveals that domestic prices for drugs are high by international standards. This reflects a combination of trade restraints and intellectual property rights (IPRs), which are the topic of the fourth section. High drug prices have led to calls for reforms to state purchasing programmes and to the rules governing patent protection for pharmaceuticals. Such efforts, if successful, would likely reduce innovation, with an uncertain net impact. Nonetheless, some reforms, notably limitations on agreements between generic-producing firms and branded-drug manufacturers that have the effect of limiting generic entry, should be considered. More generally, the strengthening of intellectual property rights since the early 1980s has been accompanied by a surge in patents, though the evidence linking this to increased innovation is slight. And some problems have resulted from the shift to stronger IPRs, most notably related to patent challenges. Some patents issued are questionable. This, combined with the rising costs of patent litigation, indicates that a post-grant opposition system that eases the process of challenging patents (and raises patent quality) could boost welfare.

The generally pro-competitive direction of regulatory policies has contributed to the strong US economic performance, but a number of challenges remain. The final topic addressed here is a review of the experience with regulatory reforms that have placed even greater emphasis on market forces. While these efforts have been very successful in most industries, issues have arisen in telecommunications and electricity - and hence these sectors are discussed in some detail. Within telecommunications, the beginning of competition for voice services in local markets following the 1996 Telecommunications Act has started to bear fruit, but policies are still needed to ensure that competitive entry in local voice services and in broadband are not thwarted by dominant carriers. At the same time, however, policy formulation must strike an appropriate balance between fostering new competition and maintaining incentives for both incumbents and new entrants to invest in and modernise telecommunication infrastructure. Technological convergence between telecommunications and information services will also require a reconsideration of universal service fees and network access charges, which is now underway. In particular, careful consideration will have to be given to as to whether the application of these legacy regulatory mechanisms might in fact inhibit technological convergence and the growth of new services.

Introducing competition into electricity markets has also proved difficult, and restructuring has stalled in the wake of the California meltdown in 2000-01. This failure reflected flaws in the regulatory framework, not the impact of competition in wholesale and retail markets. The urgency of structural reform — in addition to increased investment — has been more widely recognised since the August 2003 blackout in the northeast. Policies to increase regional transmission integration and encourage investment in transmission, and in some regions generation, are needed to improve security and efficiency. Programmes extending competition to the retail sector could benefit from domestic and international experience.

2. One further area of the US institutional framework that is both unique and costly is the tort liability system where reforms might be beneficial, especially regarding medical malpractice claims. In 2003, the Congress followed three separate tracks to enact tort reform in the areas of medical malpractice, class-action lawsuits and asbestos. All have failed thus far. For more details see Annex 5.3 and Congressional Budget Office (2003). 


\section{Competition legislation and enforcement}

The basic antitrust statutes have remained unchanged for 50 years - the Sherman Act, for over 100 years - so that policy has evolved not through changes in the law but through court decisions interpreting their general terms. Implementation has been restated over the last 30 years in terms of price theory. Since the late 1970s enforcers have emphasised strong action against horizontal price fixing coupled with close economic analysis of other restraints, monopolisation and mergers. The level of sophistication has increased, as the enforcement agencies (the Antitrust Division of the Department of Justice (DOJ), and the Federal Trade Commission (FTC)) now apply econometric tools and game theory concepts to measuring market reactions and explaining oligopoly and strategic behaviour. The federal courts generally support the price-theoretic approach, but novel economic concepts in government cases may fail to persuade them. Recent decisions have resisted agency efforts to define predation in terms of opportunity cost and to bar a distribution system because of its tendency to exclusivity.

By treating agreements among competitors about price and output or market division as crimes, US law demands that competitors actually compete. The law presumes that such agreements lead to higher prices, lower quality and/or reduced innovation. By contrast to this "per se" approach to obvious collusion, determining whether horizontal agreements of other kinds are illegal depends on applying a "rule of reasonableness", which means evaluating their net competitive effects in particular cases. These "rule-of-reason" cases are complex and time consuming. To speed up enforcement, the agencies have suggested intermediate standards for assessing the economic effects of horizontal agreements - more nuanced than per se condemnation, but less costly than full rule-of-reason analysis. The courts have not rejected the concept, but they have been sceptical of most of the tests suggested. Agreements in the vertical dimension, along the supply chain, are nearly all subject to rule-of-reason analysis, because of the stronger likelihood that they serve some efficient purpose. In theory, purely vertical agreements about minimum resale prices are illegal per se, but there is very little public enforcement at the federal level in the absence of a clear horizontal effect, and the law permits a significant degree of upstream control over resellers' sales tactics. In general, for all conduct except horizontal price fixing, US enforcement authorities do not intervene, absent some showing of economic power or market impact.

Merger policy tries to prevent market power while supporting entry and capital mobility. Policy about horizontal mergers was systematically elaborated in the regulatory agencies' 1992 Guidelines, which codify concerns about how mergers could facilitate co-ordination or increase a firm's unilateral market power. The enforcement stance is tolerant. Mergers are not challenged if there is no barrier to entering the market, and the agencies will listen to claims that mergers increase efficiency. Acquisitions of "failing firms" are treated leniently, which facilitates exit (and hence entry). The threshold at which pre-merger notice is required has been increased substantially. This change had the intended effect of greatly reducing the number of filings. Congress has insisted that special rules remain in place to control concentration in broadcasting and media. ${ }^{3}$

US law regarding monopolies threatens sanctions and even divestiture against exclusionary conduct. But unlike the law of most Member countries, otherwise it tolerates the exploitation of market power. The Sherman Act of 1890 does not prohibit a dominant firm from charging high prices or reducing output, as long as its market position is not due to improper conduct. The rationale is that permitting a firm to retain the profit from its market power would advertise an entry opportunity and avoid the contradiction of punishing vigorous competition when it succeeds. Rather, what is forbidden is conduct that achieves or maintains a monopoly by unfair means, principally by excluding other efficient competitors. Although simple exploitation is not a violation, the law strongly presumes the value of low prices, and hence it is

3. Congress has recently blocked a new FCC rule that would have let companies own TV stations serving up to 45 per cent of US viewers. The current ceiling is 35 per cent. 
sceptical about claims of price predation. "Predatory" prices violate the law only if the alleged predator could recoup its losses in conditions of post-predation monopoly unthreatened by entry. The courts continue to resist the agencies' efforts to relax this scepticism.

Measured by the range and magnitude of sanctions imposed, US enforcement appears unusually energetic. In monopolisation cases, divestiture is possible, but rare. The Antitrust Division retreated from demanding divestiture in the recent Microsoft litigation after an appellate court expressed scepticism about the appropriateness of such a remedy (in light of its revision of the district court's liability findings). Against hard-core cartels, criminal fines and imprisonment are now standard practice. The basic fine against a corporation can be up to $\$ 10$ million (and for an individual, up to $\$ 350000$ ), but that may be increased to twice the gain from the illegal conduct or twice the loss to the victims. This calculus is broadly consistent with economic models of deterrence, being based on the gain from the violation corrected for the likelihood of detection. Justifying the higher fines requires making a detailed demonstration to the sentencing judge about actual effects. Unusually, the United States prosecutes the individuals who are responsible for corporate violations and sends them to jail. The maximum prison term is three years. In 2002, sentences imposed on individuals totalled nearly 30 years, a record (Figure 1). The credible threat of tough sanctions makes the government's offer of leniency an effective tool for discouraging and discovering cartels. Insights from game theory motivated key changes that have made the leniency programme more productive. There are some concerns, though, that the motivation to confess and thus avoid fines may be undermined by the threat of treble damages in civil litigation. A bill is pending in Congress to amend the Clayton Act of 1914 so a firm that benefits from criminal leniency would be exposed only to claims for single damages; in addition, it would raise the basic corporate fine to $\$ 100$ million and increase the maximum prison term to 10 years. ${ }^{4}$

Private litigation is unusually important in the United States. About 800 antitrust cases are filed each year (723 in 2001, 830 in 2002), of which only about 10 per cent are US government enforcement actions. These are not all trivial disputes: a recent case awarded over $\$ 1$ billion (and this award was confirmed on appeal). In these private suits, the courts deal with issues such as price discrimination and vertical restraints that are not high priorities in the agencies' enforcement programmes. The original Sherman Act, and later the Clayton Act, promise treble damages and attorneys' fees to promote deterrence and compensate for the difficulty of detecting covert unlawful activity. But now that class actions facilitate aggregating claims and criminal fines have greatly increased, the incremental value of awarding exemplary damages ought to be reconsidered, particularly if they undermine the effectiveness of the leniency programme.

The two federal agencies commit about 1275 staff (FTE) to competition enforcement. Because of the law's strong economic content and the analytic demands of complex cases, each keeps scores of $\mathrm{PhD}$ economists on staff. The agencies' functions and powers are broadly similar, the principal differences being that only the DOJ deals with criminal cases and only the FTC has responsibility for consumer protection and advertising. Outright conflicts, duplication and forum shopping have been avoided, but the redundancy imposes some costs on each agency to co-ordinate policies and actions with the other. The roles of state officials must also be considered. State enforcers have tried to block some mergers and vertical restraints that the federal enforcers did not challenge. In recent years, the federal agencies and state enforcers have developed better means of co-operation to reduce direct conflicts, but disagreements persist. Notably, a group of states rejected the government's settlement of the Microsoft case, and one persisted in seeking stronger relief.

4. In some non-price-fixing cases, government actions have led to remedies requiring firms to disgorge unlawful gains or make restitution to victims. The sums have been very large — in one case, over $\$ 100$ million. Technically, these are not considered damages, but the cases were co-ordinated with state and private claims for damages. 
Figure 1. Competition law enforcement
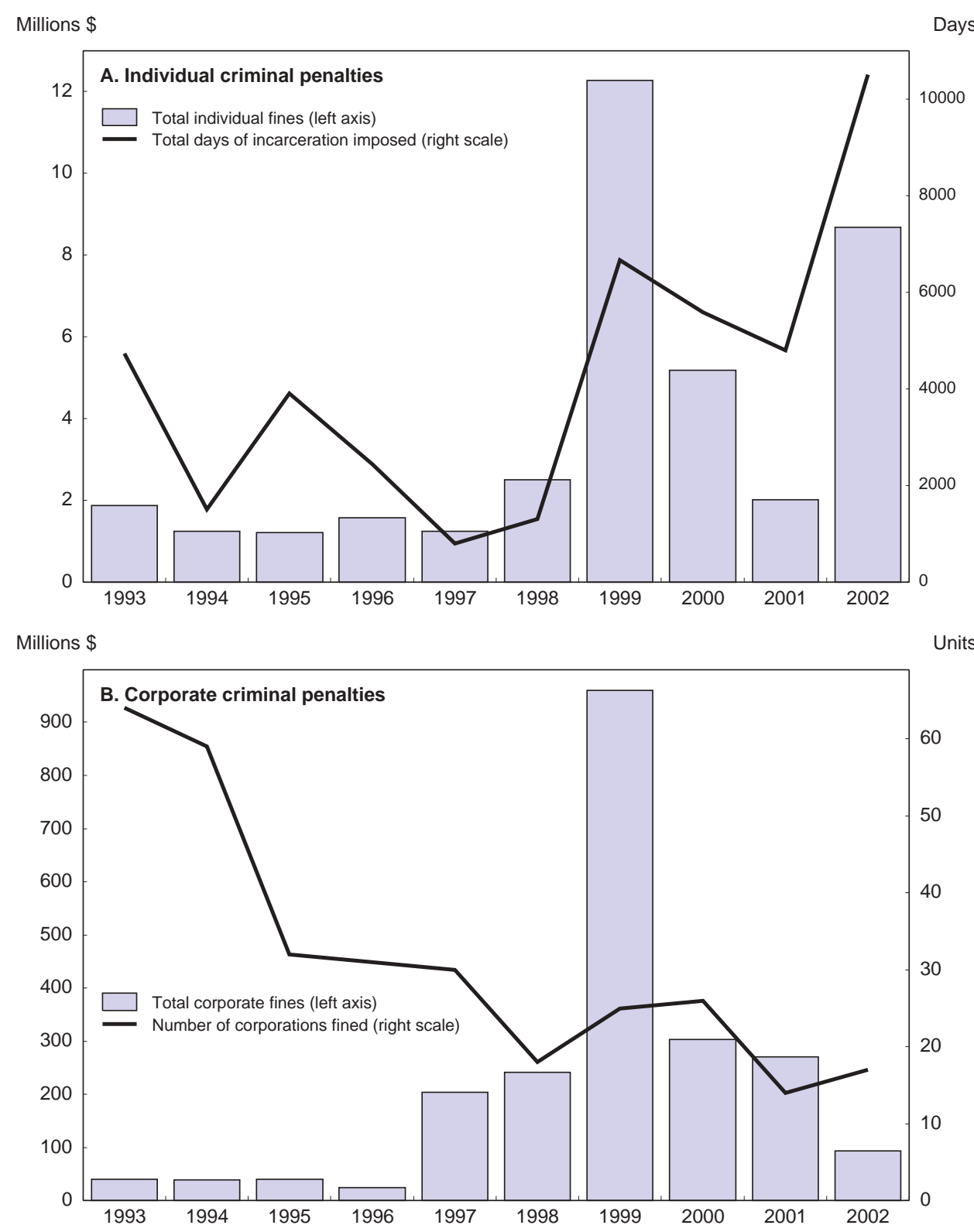

Source: US Department of Justice.

The serious consequences of violating the law encourage claims for exemption, special treatment or even regulation as a substitute for competition law enforcement. There are few sectors in the US economy from which competition policy and law are completely excluded. But in many sectors, the policy is implemented through special rules or enforcement structures. Some of these make no practical difference, but others look like special-interest protections, and many were obviously enacted to undo enforcement. Separate enforcement systems for meat packing and agricultural co-operatives date from the 1920 s, prompted by early FTC monopolisation cases against these organisations. Other laws have reversed findings against pooling of sports broadcast rights, against manufacturing and distribution agreements in the soft drink industry, against price-fixing in the insurance industry, and against agreements among 
universities about financial aid awards. Many non-profit enterprises are exempt from Section 5 of the FTC Act of 1914, a historical oddity that impairs action against their commercial misconduct.

Sector-specific agencies have competition policy roles. Their performance of these roles varies. Some apply competition policies reasonably consistently with the competition agencies. Where antitrust laws and regulation co-exist, convergence is most obvious. In gas and oil pipelines, for example, "regulation" typically amounts to a hands-off decision to allow market forces to work, as long as the market is not too concentrated. In electric power, though, this is complicated by deference to state regulation at retail level. In telecoms, divestitures following an antitrust suit launched restructuring 20 years ago, but changes have stalled due to compromises in the settlement and in Congress's 1996 legislative intervention (see below). In transport, the experience with separate agencies has been disappointing, as they have permitted mergers that led to market power and have sustained exemptions and anti-competitive practices that should be reined in. For example, in ocean shipping, the regulatory scheme permits cartel conduct that would be illegal in other sectors, while the Federal Maritime Commission has taken only a few tentative actions under its mandate to protect competition; and in surface transport, motor freight rate bureaux still have antitrust immunity for agreements about some subjects.

The "state action doctrine" is an important gap in US antitrust policy. A clear, affirmative, and actively supervised state government policy to displace competition immunises private anti-competitive conduct from liability under federal law. Embodying the US commitment to federalism, the doctrine stems from a 1943 Supreme Court decision that permitted a state to sponsor a cartel. Later decisions have permitted anti-competitive state regulation of transportation, hospitals, health care and other professional services, retail distribution, utilities, residential and commercial rent, and other subjects. Congress could override such decisions, and it did so when it voided widespread anti-competitive state regulation of local trucking. The extent of deference to states' sovereignty risks embarrassing the national commitment to competition. Yet a September 2003 FTC study of the issue treated only technical issues about the interpretation of doctrine and did not examine market effects or identify sectors where state-level constraints on product market competition should be removed.

Another gap involves government entities, which are generally beyond the reach of competition law enforcement or private litigation even if they are involved in commercial operations. Entities that are owned and operated by the US government are immune by federal law, while the state action doctrine shields those of state and local governments. The immunity may be particularly significant for electric power systems, hospitals and port authorities, where private competitors have complained that the government entities enjoy unfair competitive advantages.

\section{Strong competitive forces have contributed to good economic performance}

The US economy has performed comparatively well since 1990, despite the recent recession (Table 1). At the aggregate level, average GDP growth between 1990 and 2002 was the highest of the G7 countries, and above the OECD and European Union averages. The level of GDP per capita remains the highest among the G7, and GDP per hour worked has continued to be near the top. The good performance has reflected both productivity and employment growth over the period. Moreover, productivity growth accelerated markedly over the second half of the 1990s, and there has been a further acceleration more recently. While the relationship between policies affecting competition at the microeconomic level and aggregate performance remains somewhat tenuous, a number of recent studies have documented important linkages. 
ECO/WKP(2004)21

Table 1. Recent trends in output, employment and productivity

\begin{tabular}{|c|c|c|c|c|c|c|c|c|c|}
\hline & $\begin{array}{l}\text { United } \\
\text { States }\end{array}$ & Japan & Germany & France & Italy & $\begin{array}{l}\text { United } \\
\text { Kingdom }\end{array}$ & Canada & OECD & $\begin{array}{l}\text { European } \\
\text { Union }\end{array}$ \\
\hline $\begin{array}{l}\text { Average GDP growth, } 1990-2002^{1} \\
\text { of which: }\end{array}$ & 2.9 & 1.5 & 1.4 & 1.9 & 1.5 & 2.2 & 2.7 & 2.6 & 2.1 \\
\hline Labour productivity & 1.7 & 1.3 & 1.3 & 1.2 & 1.2 & 1.9 & 1.3 & 1.1 & 1.0 \\
\hline $\begin{array}{l}\text { Employment } \\
\text { of which: }\end{array}$ & 1.2 & 0.3 & 0.1 & 0.7 & 0.3 & 0.3 & 1.3 & 1.5 & 1.0 \\
\hline Unemployment $^{2}$ & 0.0 & -0.2 & -0.3 & 0.0 & 0.1 & 0.1 & 0.0 & -0.1 & 0.0 \\
\hline Labour force & 1.2 & 0.5 & 0.3 & 0.7 & 0.2 & 0.2 & 1.3 & 1.6 & 1.0 \\
\hline Demographics $^{3}$ & 1.2 & 0.6 & 0.2 & 0.8 & 0.2 & 0.2 & 1.4 & 1.7 & 0.7 \\
\hline Participation rates ${ }^{4}$ & 0.0 & -0.1 & 0.2 & -0.1 & 0.0 & 0.0 & 0.0 & -0.1 & 0.3 \\
\hline $\begin{array}{l}\text { Average GDP growth, 1995-2002 } \\
\text { of which: }\end{array}$ & 3.2 & 1.1 & 1.5 & 2.4 & 1.8 & 2.8 & 3.6 & 2.7 & 2.3 \\
\hline Labour productivity & 1.9 & 1.4 & 1.0 & 1.1 & 0.8 & 1.7 & 1.5 & 1.7 & 1.1 \\
\hline $\begin{array}{l}\text { Employment } \\
\text { of which: }\end{array}$ & 1.3 & -0.2 & 0.5 & 1.3 & 1.0 & 1.1 & 2.0 & 1.1 & 1.2 \\
\hline Unemployment $^{2}$ & 0.0 & -0.3 & 0.0 & 0.4 & 0.3 & 0.6 & 0.4 & 0.1 & 0.4 \\
\hline Labour force & 1.3 & 0.1 & 0.5 & 0.8 & 0.7 & 0.5 & 1.7 & 1.0 & 0.9 \\
\hline Demographics ${ }^{3}$ & 1.0 & -0.5 & -0.5 & 0.4 & 0.3 & 0.2 & 1.0 & 0.8 & 0.2 \\
\hline Participation rates ${ }^{4}$ & 0.3 & 0.6 & 0.9 & 0.5 & 0.4 & 0.3 & 0.7 & 0.2 & 0.6 \\
\hline Memorandum items: & & & & & & & & & \\
\hline MFP growth, ${ }^{5} 1991-2002$ & 0.9 & 0.1 & 0.6 & 0.5 & 0.7 & 1.1 & 0.9 & n.a. & n.a. \\
\hline MFP growth, ${ }^{5} 1995-2002$ & 1.1 & 0.3 & 0.2 & 0.7 & 0.1 & 0.7 & 1.2 & n.a. & n.a. \\
\hline GDP per capita ${ }^{6}$ & 100.0 & 74.0 & 73.4 & 74.2 & 72.0 & 73.8 & 83.8 & 71.3 & 71.7 \\
\hline GDP per hour worked ${ }^{6}$ & 100.0 & 73.2 & 93.2 & 110.1 & 94.6 & 85.5 & 86.5 & 81.8 & 92.3 \\
\hline
\end{tabular}

1. Except Germany: 1992-2002.

2. A positive sign indicates that unemployment has declined and contributed to boost output growth.

3. The contribution from demographics comprises changes in the size and age composition of the working-age population.

4. This measures the effect from changes in age-specific participation rates.

5. Total economy.

6. 2002 levels, PPP based, USA $=100$.

Source: OECD.

One set of indicators used to document links between competition policies (broadly defined) and aggregate economic performance has been developed at the OECD to provide a quantitative summary of the extent of regulation affecting competition. ${ }^{5}$ Such measures of the extent of barriers to trade and of administrative and economic regulations generally show that the United States is quite open to competitive pressures, although some OECD countries (the United Kingdom in particular) have even lower obstacles to product market competition (Figure 2). It is also important to note that such indicators show that competitive forces have been stronger in the United States than in most other Member countries for some time.

By these measures, restrictions on product market competition are inversely related to multifactor productivity growth, suggesting that the low barriers in the United States have contributed to its good performance relative to continental Europe (Nicoletti and Scarpetta, 2003). Similar stimulative effects have been found on investment (Alesina et al., 2003). Thus, low barriers to entry in the United States have likely played a part in generating strong labour productivity growth through both increased multifactor productivity and greater capital deepening. And product market competition has probably helped maintain policies conducive to labour market competition, as low rents decrease the incentives for workers to engage in "rent seeking" by lobbying for employment protection policies (Blanchard and Giavazzi, 2002).

5. The indicators are based on detailed data collected by the OECD from national sources. Summary indicators are computed aggregating individual regulations with weights derived from factor analysis. The resulting country rankings are robust to changes in the weighting procedure. 
A liberal labour market in the United States has ensured that productivity-enhancing technologies — which by definition imply weaker employment growth than otherwise or labour-shedding, at least from existing activities - are adopted quickly (Feldstein, 2003). This channel has been quantitatively important in explaining the diffusion and productivity impact of information and communications technologies (ICT) in the United States, and hence relatively strong growth performance after 1995 (Gust and Marquez, 2002).

Figure 2. Indices of regulations affecting product market competition 0-6 indicator from least to most restrictive

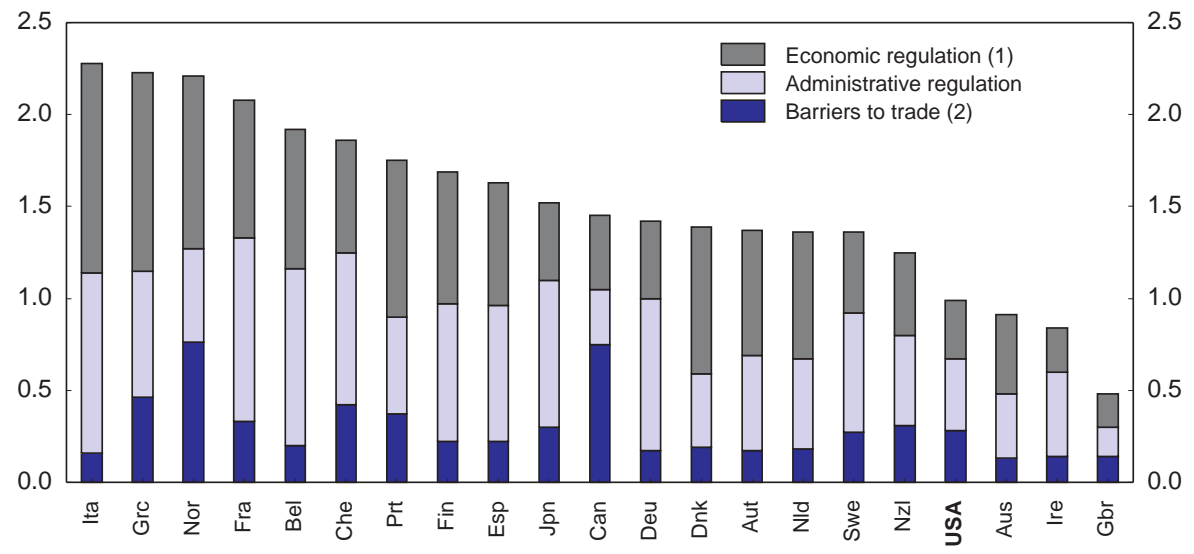

1. Includes barriers to competition and state control.

2. Includes trade and FDI restrictions.

Source: Nicoletti and Scarpetta (2003).

A competitive environment also boosts research and development and the diffusion of technologies, among the primary factors contributing to long-run economic growth (Ahn, 2002; OECD, 2003). Firms are forced to make such knowledge investments to avoid losing market share in the longer run. The United States has one of the highest rates of investment in R\&D and is a world leader in development (if not production) in a number of leading knowledge-based industries - notably computer hardware and semiconductors, software, pharmaceuticals and biotechnology (Figure 3). In addition to the impetus from competition and the favourable effect of market size, such innovative activity may have been boosted by strong intellectual property rights (IPRs), which increase the returns received (see below).

Figure 3. Gross domestic expenditure on R\&D as a percentage of GDP $2001^{1}$

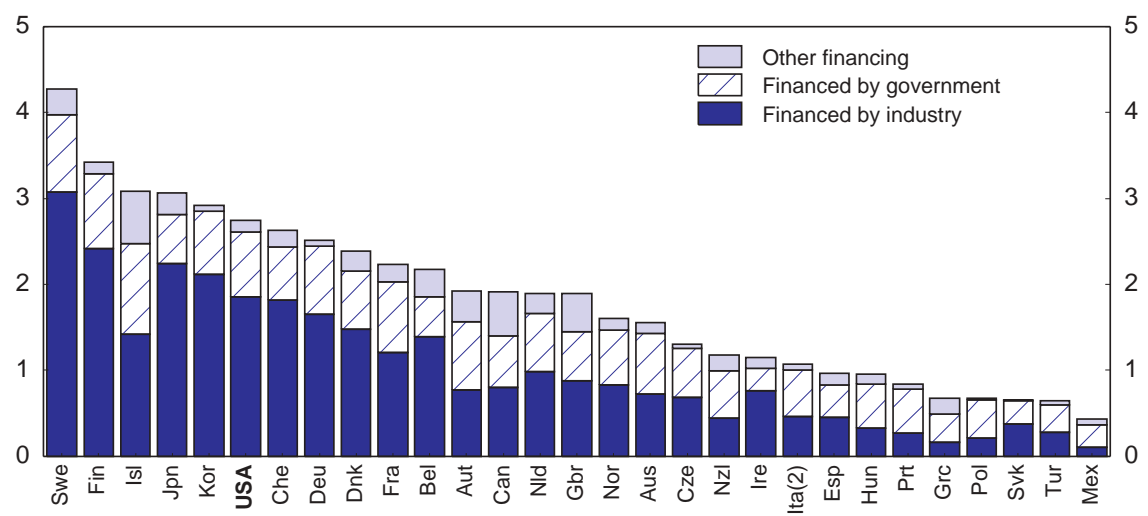

1. Australia, Ireland, Italy, Switzerland, Turkey: 2000; Greece, Mexico: 1999.

2. The breakdown between private and public expenditure for Italy was unavailable. The 2000 figure was estimated using weights from 1996, which was the latest year for which the breakdown is available.

Source: OECD, Main Science and Technology Indicators (2003/1). 


\section{Barriers to foreign trade are relatively low}

The importance of foreign competition ${ }^{6}$ in US (and other) markets is difficult to assess. Complications arise because domestic markets can be insulated in many ways: tariffs; explicit non-tariff barriers such as quotas and voluntary export restraints; policies that indirectly discriminate against foreign products such as health, safety, labelling and certification requirements (although such standards often serve legitimate welfare objectives); government procurement policies; heavy-handed customs procedures; and threatened or levied anti-dumping and countervailing duties that cannot be justified (see below). Indeed, such measures should be held to the same standards as on domestic markets. An empirical analysis for a panel of 21 OECD countries, which uses a crude country-size-adjusted measure of trade exposure to capture competitive pressures, suggests that an increase in trade exposure by 10 percentage points raises output per capita by 4 per cent (OECD, 2003). According to this measure, the United States has become more open to foreign competition over the past two decades, like many other OECD countries.

Given the many possible methods to prevent foreign access to domestic markets and the difficulty of summarising such effects in an empirical model, the information conveyed by prices provides a metric whereby the strength of arbitrage across national boundaries that disciplines domestic firms' price-setting behaviour can be assessed. Such comparisons must compare similar goods and adjust for net indirect taxes and transportation costs. ${ }^{7}$ A recent study develops comparisons of domestic prices to world prices for 124 goods based on the prices collected by the OECD to compute purchasing power parities, which are converted to producer prices and adjusted for transport costs (Bradford, 2003). Unfortunately, data availability (and the labour intensity of such calculations) limited the statistics to eight countries covering price quotes from 1991 to 1993. Although these measures are not perfect, the results, summarised for 29 industries in Table 2, indicate that the United States (with an "effective tariff", i.e. the percentage differential between domestic and world price, of under 12 per cent) was a decade ago easily the most open of the countries considered. In 18 sectors its price was the lowest of the eight countries and in a further eight sectors it ranked second.

The sectoral breakdown of the results is also informative. US relative prices were nearly uniformly low with one major exception. The comparison indicates that drugs and medicines were dramatically more expensive in the United States than in the low-price country (Australia) and more expensive than in most other countries considered as well. ${ }^{8}$ This differential is well known - for example, it is not uncommon to find newspaper reports describing US consumers' trips to Canada (or Mexico) for cheaper prescription drugs. This partially reflects US safety-based restrictions on parallel importing to prevent counterfeit and untested products. Although the European Union (EU) permits parallel importing (internally), it also restricts imports from third countries due to concerns over counterfeit and defective

6. Foreign competition should be understood here in broad terms. Besides the disciplinary impact of traditional imports of goods (and savings) from foreign producers, wages and prices are squeezed down to their minimum levels by intermediate or final-product imports from related parties or other parts of the value added chain that are outsourced abroad. Outsourcing, especially in the high-technology area, has become very controversial during the "jobless recovery". The US statistical agencies just announced their intention to try to track the magnitude of this growing phenomenon. And the Senate voted to prevent federal contractors from outsourcing work abroad in the FY 2004 omnibus appropriations bill that passed in January.

7. A large literature compares unit values derived from trade data to assess price gaps across countries (e.g. Knetter, 1994 and Swagel, 1995). Such comparisons are valuable at very detailed classification levels (for example, the 10-digit level of the harmonised trade system), but differences in goods at higher levels of aggregation make them much less informative.

8. A recent study (Danzon and Furukawa, 2003) that uses data for 1999 and concentrates on drug prices also finds that US drug prices are higher than in other countries (except Japan) but less so than Bradford. 
medicinal products. The interaction between IPRs and competition, especially in pharmaceuticals, is discussed at the end of this section.

Table 2. Ratio of the domestic to the world price, 1991-93

\begin{tabular}{|c|c|c|c|c|c|c|c|c|}
\hline Industry & Australia & Belgium & Canada & Germany & Japan & Netherlands & $\begin{array}{l}\text { United } \\
\text { Kingdom }\end{array}$ & $\begin{array}{l}\text { United } \\
\text { States }\end{array}$ \\
\hline Agriculture, fisheries and forestry & 1.067 & 1.157 & 1.112 & 1.529 & 1.584 & 1.080 & 1.648 & 1.158 \\
\hline Processed food & 1.086 & 1.372 & 1.192 & 1.447 & 2.099 & 1.299 & 1.202 & 1.090 \\
\hline Beverages & 1.447 & 1.444 & 1.535 & 1.765 & 1.540 & 1.328 & 1.694 & 1.061 \\
\hline Tobacco & 1.472 & 1.947 & 1.955 & 3.531 & 1.000 & 1.385 & 2.217 & 1.060 \\
\hline Textiles & 1.111 & 1.218 & 1.163 & 1.101 & 1.478 & 1.140 & 1.237 & 1.051 \\
\hline Apparel & 1.264 & 1.569 & 1.175 & 1.457 & 1.384 & 1.280 & 1.074 & 1.158 \\
\hline Leather and products & 2.944 & 1.777 & 1.236 & 1.437 & 1.329 & 1.658 & 1.168 & 1.143 \\
\hline Footwear & 1.657 & 1.823 & 1.415 & 1.328 & 2.289 & 2.239 & 1.027 & 1.111 \\
\hline Furniture and fixtures & 1.299 & 1.958 & 1.558 & 1.392 & 2.707 & 1.471 & 2.172 & 1.020 \\
\hline Paper and products & 1.438 & 1.659 & 1.060 & 1.606 & 1.804 & 1.965 & 1.783 & 1.050 \\
\hline Printing and publishing & 1.120 & 1.310 & 1.205 & 1.024 & 1.186 & 1.342 & 1.029 & 1.005 \\
\hline Drugs and medicines & 1.001 & 1.692 & 2.680 & 2.643 & 1.217 & 3.349 & 1.845 & 3.105 \\
\hline Chemical products & 1.092 & 1.137 & 1.064 & 1.107 & 1.555 & 1.075 & 1.064 & 1.037 \\
\hline Petroleum and coal products & 2.127 & 3.375 & 1.320 & 2.847 & 3.359 & 4.335 & 4.067 & 1.007 \\
\hline Rubber products & 1.219 & 1.680 & 1.015 & 1.711 & 2.016 & 1.655 & 1.566 & 1.032 \\
\hline Pottery, china, etc. & 1.727 & 1.007 & 1.145 & 1.511 & 2.383 & 1.016 & 1.082 & 1.070 \\
\hline Metal products & 1.430 & 1.622 & 1.328 & 1.770 & 1.977 & 1.837 & 1.602 & 1.165 \\
\hline Office and computing machinery & 1.008 & 1.513 & 1.234 & 1.446 & 1.000 & 2.101 & 1.666 & 1.015 \\
\hline $\begin{array}{l}\text { Machinery and equipment, nec } \\
\text { Radio, TV and communication }\end{array}$ & 1.343 & 1.682 & 1.297 & 1.325 & 1.559 & 1.527 & 1.388 & 1.175 \\
\hline equipment & 1.178 & 1.558 & 1.204 & 1.298 & 1.226 & 1.432 & 1.236 & 1.034 \\
\hline Electrical apparatus, nec & 1.536 & 1.936 & 1.316 & 1.713 & 2.106 & 1.556 & 1.320 & 1.073 \\
\hline Shipbuilding and repairing & 1.278 & 1.267 & 1.107 & 1.354 & 1.200 & 1.545 & 1.536 & 1.000 \\
\hline Railroad equipment & 1.374 & 1.314 & 1.093 & 1.404 & 1.238 & 1.509 & 1.503 & 1.016 \\
\hline Motor vehicles & 1.224 & 1.351 & 1.197 & 1.315 & 1.000 & 1.648 & 1.680 & 1.106 \\
\hline Motorcycles and bicycles & 1.231 & 1.761 & 1.252 & 1.599 & 1.000 & 1.385 & 2.002 & 1.057 \\
\hline Aircraft & 1.191 & 1.199 & 1.082 & 1.282 & 1.020 & 1.462 & 1.454 & 1.001 \\
\hline Transport equipment, nec & 1.516 & 2.034 & 1.109 & 1.888 & 1.315 & 2.065 & 1.924 & 1.057 \\
\hline Professional goods & 1.125 & 1.571 & 1.082 & 1.379 & 1.077 & 1.369 & 1.586 & 1.074 \\
\hline Other manufacturing, nec & 1.237 & 1.807 & 1.209 & 1.863 & 2.348 & 1.636 & 1.416 & 1.030 \\
\hline Weighted geometric means & 1.266 & 1.555 & 1.270 & 1.539 & 1.567 & 1.541 & 1.480 & 1.118 \\
\hline
\end{tabular}

Source: Bradford (2003).

\section{Leadership to successfully conclude the Doha round is needed}

In addition to its openness to foreign competition, the United States has also continued to pursue further trade liberalisation. Beside bilateral free-trade negotiations (Chapter 1), the Administration has continued to hold talks on a Free Trade Area of the Americas, which would open trade within the Western hemisphere. Most importantly, negotiations regarding the Doha round are underway. The US proposal to eliminate export subsidies in agriculture and reduce other trade distortions in that area is welcome - as is the proposed elimination of industrial and consumer goods tariffs by 2015 . However, progress has still to be forthcoming.

Despite the relative openness of the economy and the positive set of proposals for the Doha round, a stronger push to conclude the negotiations would be welcome. One area where a renewed focus may lead to significant welfare gains is on efforts to reduce global anti-dumping and safeguard actions starting with a curtailment of domestic use of these tools. The United States (along with the European Union) has been a major user of such measures; the experience in the last several years with anti-dumping and countervailing duty sanctions against Canadian softwood lumber and the safeguard measures regarding steel, both discussed in Chapter 1, are only the latest examples. From a pure welfare economics perspective, neither tool is easy to justify; rather, both result in higher prices for consumers and 
impede necessary adjustments that would lead to a superior (long-run) allocation of resources. ${ }^{9}$ For example, a study of the cost of anti-dumping orders in place as of 1993 found that these lowered welfare by $\$ 2$ to $\$ 4$ billion annually, making anti-dumping actions one of the costliest US trade protection measures (Gallaway et al., 1999).

Nonetheless, the creation of the World Trade Organisation (WTO) solidified the international standing of anti-dumping and safeguard actions, in part to lower reliance on "extra-legal" forms of protectionism such as voluntary export restraints. Two after-effects are now apparent. First, the use of anti-dumping and safeguard measures by countries that are not OECD members (who traditionally have been the major users, except Japan) has surged; while OECD members accounted for more than 95 per cent of anti-dumping actions in the late 1980s, this proportion had fallen to about 50 per cent by the second half of the 1990s. Second, the WTO has taken a tough stand regarding whether such actions fall within permissible boundaries since its inception in 1995. In the twelve anti-dumping cases decided by May 2003, the challengers prevailed on at least one significant issue (Tarullo, 2003), and each of the six US safeguard actions has had some aspect deemed in violation of WTO obligations (Irwin, 2003). Some analysts have suggested that this set of WTO decisions does not accord well with the deference to national authorities regarding anti-dumping determinations that rest on "permissible interpretations" under Article 17.6 of the Anti-Dumping Agreement. ${ }^{10}$ Perhaps as a result, the Congress has established a principal negotiating objective for the Doha round that negotiators seek to preserve the ability of the United States to enforce its trade laws, including anti-dumping law. This set of developments has taken the issue beyond simple welfare economics; while the static efficiency gains from tight standards of review at the WTO could be used to justify its decisions, a number of commentators (e.g. Sykes, 2003 and Tarullo, 2003) have emphasised the political cost of rigid enforcement, and hence possible long-run damage to the trading system.

The best outcome would involve US leadership to maintain a strong dispute resolution system that encourages less reliance on anti-dumping and safeguard actions. This could start by stepping back from the tariffs levied recently (as in the case of steel products) and by refraining from further protectionist measures. It may also be useful to strengthen the economic analysis used in making safeguard determinations. The current standard comes dangerously close to a "correlation equals causation" argument; i.e. the finding of serious harm from imports necessary for a safeguard action does not usually reflect a careful evaluation of the exogenous changes in supply and demand conditions in the industry (Sykes, 2003; Irwin, 2003), and improved efforts in this regard appear possible (Irwin, 2003).

\section{Intellectual property rights}

The relatively higher level of domestic drug prices noted above reflects the interaction of several factors, including adherence to a free-market policy, concerns about untested foreign products, a belief in the future benefits of technological innovation and the strong enforcement of intellectual property rights (IPRs). But the importance of IPRs is far greater - particularly in assessing the strength of competitive forces in the economy. They are a building block of the modern knowledge economy, playing a central role in information technology, life sciences (such as pharmaceuticals and biotechnology) and beyond. They provide incentives to research and to disclose information. Well-defined rights to the returns

9. A rationale for anti-dumping actions as efficiency-enhancing is particularly difficult; predatory pricing to gain a monopoly position is one such justification, but antitrust law generally (though not universally) views claims of predatory actions sceptically. Safeguard actions could be justified if, for example, an otherwise (long-run) efficient industry faces capital market imperfections that impede it from making the adjustment to a competitive long-run position; however, this example would call for loan guarantees rather than tariffs, and it is not clear that any current safeguard action could be justified on these grounds.

10. Tarullo (2003) provides references to studies on both sides of this issue. 
from discoveries may promote technology transfer to rivals at home and abroad. But these potential benefits must be weighed against the social costs stemming from the temporary monopoly power they provide to protected innovations. Moreover, IPR policies have been changed significantly over the past two decades, and an assessment of the benefits and costs of these reforms is overdue. ${ }^{11}$ The following sections discuss, in turn, the recent evolution of patent rights and their impact on research and innovation, and the role of patent protection in the pharmaceutical industry and especially on drug prices - in each case with an eye to possible modifications to current practices.

\section{Lessons from patent reforms}

Patenting has risen sharply since the early 1980s, more than tripling by 2001 (Figure 4). This increase occurred in the wake of several significant changes that resulted in stronger patent rights. A series of court decisions from 1980 to 1998 extended (or affirmed) patentability of genetically engineered bacteria, software and business methods and financial services products. In 1982, the Court of Appeals of the Federal Circuit (CAFC) was established as the central forum for patent cases; prior to this, cases were heard in federal circuit courts around the country, leading to "forum shopping" for patent-friendly or patent-sceptical courts. The CAFC brought consistency to patent decisions, but was also accompanied by a significant broadening in patent-holders' rights (Lerner, 2002). On top of these changes, the US Patent and Trademark Office (PTO) became solely funded by fees in 1999, and compensation for patent examiners has lagged those of comparable private-sector positions. Critics have suggested that the threshold for patent issuance has fallen as a result. Finally, the global Trade-Related Aspects of Intellectual Property (TRIPS) agreement of 1994 led to a change in US patent length from 17 years following patent issuance to 20 years from patent application (with some important exceptions related to pharmaceuticals). While research has linked the surge in patenting to these changes (Hall, 2003), other factors, such as improved management and more focus on applied research, have perhaps been more important (Kortum and Lerner, 1998).

Figure 4. Domestic patent grants 1970-2001

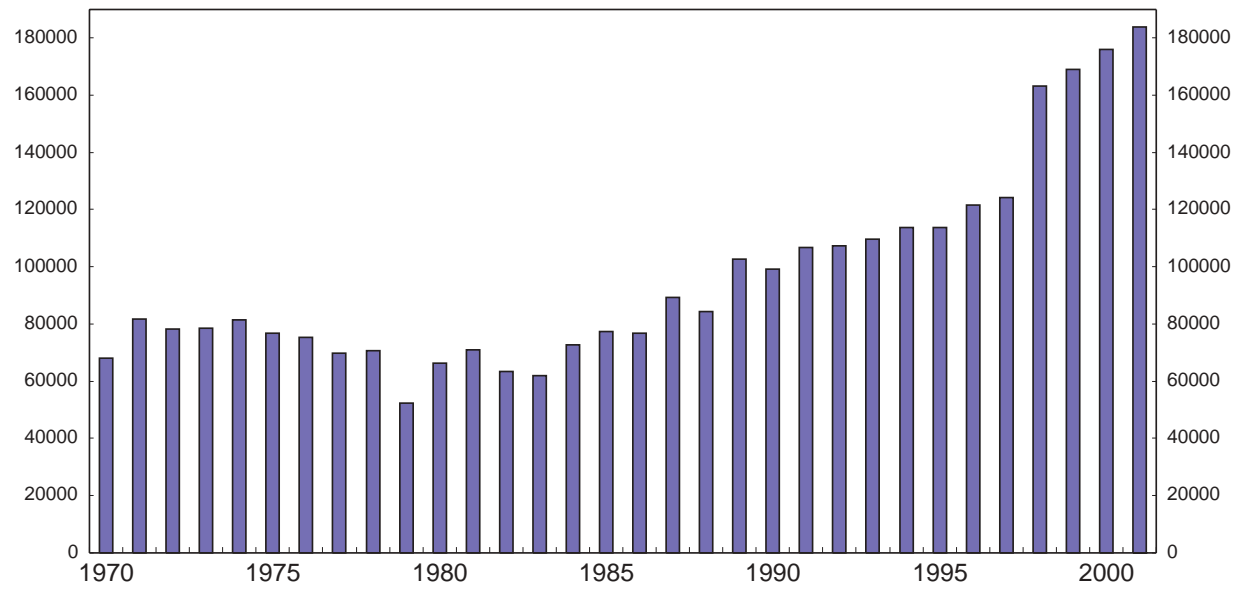

Source: US Patent and Trademark Office.

Although the surge in patents has coincided with an expansion in R\&D expenditure, there is not much evidence that innovation has increased as a result of a patent reform (Jaffe, 2000; Gallini, 2002). One

11. An ongoing project within the OECD on IPRs, innovation and economic performance is studying these issues in more detail. 
factor may be that patents are not the most effective way to protect intellectual assets: surveys of companies suggest that superior sales and service, lead time and secrecy are far more important in securing returns to innovation than patents (Cohen et al., 2000; Arundel, 2001) - except in the pharmaceutical industry (and perhaps some others), a point returned to below. In assessing whether the strength of patent rights in the United States has moved beyond the optimal level, the question is whether too much current income and output is sacrificed for the additional innovation generated.

The upturn in patenting has nevertheless facilitated some positive developments. Perhaps most importantly, strong patent protections facilitate vertical specialisation and entry of firms specialising in intellectual assets by allowing them to attract financial capital and by lowering the transaction costs associated with negotiating contracts (Lerner, 1994). Studies have demonstrated the importance of these channels in industries where patent rights are easy to define, such as biotechnology and chemicals (e.g. Arora and Fosfuri, 2000; Anand and Khanna, 2000). And the growth of design-only firms in the semiconductor industry has owed significantly to the strengthening of patent protections since 1980 (Hall and Ziedonis, 2001). However, even this positive development has been accompanied by negative side-effects in some cases, most notably a rise in patent litigation. Agreements regarding patent licensing can also lead to anticompetitive behaviour; the Department of Justice and Federal Trade Commission's Antitrust Guidelines for the Licensing of Intellectual Property attempt to balance the potentially pro- and anti-competitive aspects of licensing (Gilbert and Tom, 2001). Patent pooling by rival firms can either contribute to the exercise of market power - for example, when the patented items are potential substitutes - or aid the development of essential standards for complementary innovations (Shapiro, 2001). ${ }^{12}$

The discussion has highlighted concerns regarding the strength of patent protections. Of course, property rights are likely to be a more effective means to spur innovation than alternatives such as prizes or auctions when the value and cost of projects are not easily discernible because those firms with superior information are provided with incentives under IPRs (Gallini and Scotchmer, 2001). Nonetheless, some changes to current practices would lead to a better balance between these incentives and the negative distortions created under the existing system. The "litigation tax" associated with the current patent right system has become significant, with patent litigation per patent increasing by 50 per cent from the early 1980s to the late 1990s (Hall et al., 2003). While it is difficult to quantify exactly, Lerner (1995) estimated that the cost of litigation associated with patents issued in one year (1991) would exceed one-quarter of total expenditures on basic research by private firms in that year. Two aspects of the current system contribute to the high level of litigation: first, the fall in the quality of patent application reviews at the PTO that has accompanied an expansion in the breadth of patentable material and the relative decline in examiners' compensation, and then the limited nature of third-party review of what are called prior-art searches. The current re-examination procedure allows a patent holder or any other party to request that the PTO reconsider the grounds on which a patent was issued by presenting prior art that is previously unknown to the PTO and relevant. The prior art must have been printed in an earlier patent or publication. Challengers are (essentially) not involved in the re-examination beyond notifying the PTO of the prior art. In Europe, challenges to patents issued by the European Patent Office can be brought by a third party within nine months of the patent grant by presenting evidence that the patent is not valid. Moreover, the challenger has the right to appeal the patent office's decision. The European system has led to a much larger number of successful administrative challenges to patents: the ex post probability that a patent will be revoked via a challenge has been about 3 per cent in Europe but essentially zero in the United States (0.02 per cent) (Hall et al., 2003). A move to an opposition system in the United States would reduce patent litigation but might lead to more opposition of cases that should not be challenged. Nonetheless, on

12. A more thorough set of references to antitrust concerns and IPRs can be found in Gallini (2002). 
balance, an opposition system is likely to be cheaper and lead to better outcomes according to a number of experts. $^{13}$

Two other areas where reforms should be considered are the scope of business method patents and the degree to which firms or researchers can use information provided in a patent to develop new innovations, especially related to software. A recent summary of research (Hall, 2003) finds that most scholars view the standards for patent issuance in the business methods area to be too low and recommends a tightening in the "non-obviousness" requirement in this area. (A trivial example of this problem is the recent issuance of a patent on a method to cut hair with scissors using two hands simultaneously). With regard to "reverse-engineering" of patented material in order to facilitate invention, current policies that (potentially) award treble damages if wilful infringement of a patent is found may limit progress in software development. An exception for software that allows duplication of non-patented elements and use of components necessary for interoperability and interface should be considered. ${ }^{14}$

\section{Intellectual property rights and pharmaceuticals}

While patent protections may not be among the most important methods used to reap the profits from innovation in many industries, they are vital in the pharmaceutical industry (Cohen et al., 2000; Arundel, 2001). US pharmaceutical patents receive special treatment because the process regulating drug introductions can take a long time. The Drug Price Competition and Patent Restoration Act of 1984 (known as the Hatch-Waxman Act) was designed to address this issue, promoting innovation and easing generic drug approval. It restored up to five years of patent time lost to pre-market clinical testing and the Food and Drug Administration (FDA) approval process and allowed generic entry without the duplication of certain testing. The original statute also provided for a 180-day exclusivity period to the first applicant to apply to manufacture a generic and challenge an existing patent of the innovation. Branded drug manufacturers were entitled to a 30-month postponement of FDA approval of a generic application when the generic might have infringed on a patent related to the drug. ${ }^{15}$

The interaction of the 30-month delay in approval and the 180-day exclusivity had raised concerns about anticompetitive effects. In certain agreements, generic firms agree not to market the drug for which they have requested generic drug approval and the branded drug company consents to making payments to the generic firm. Because of the 180-day exclusivity provision of the Hatch-Waxman Act, these agreements prevented generic entry for some time for certain drugs. The Federal Trade Commission (FTC) and private plaintiffs have challenged a number of these agreements as violations of antitrust laws; to date, the FTC and the courts have limited their arguments to the facts associated with any one agreement and have not acted to make them per se illegal. Agreements regarding patent disputes should not be discouraged, as they may resolve conflicting claims in an efficient matter. But two reforms should be considered ${ }^{16}$ : since the purpose of the 180-day exclusivity period is to strengthen the entry incentive (because, for example, the generic may face a cost disadvantage relative to the incumbent), agreements that delay entry should provoke revocation of the exclusivity period; there should also be limits

13. Two surveys are Levin and Levin (2002) and Hall et al. (2003). Other studies include Janis (1997), Barton (2000 and 2001) and Wegner (2001).

14. Interoperability and interface are the abilities to work with some other patented programmes, especially operating systems but also other platforms, and to match the look of patented programmes.

15. The 2003 Medicare Prescription Drug, Improvement and Modernisation Act limits the 30-month postponement to a single delay in almost all instances (rather than having multiple consecutive postponements for multiple disputes). Moreover, the 180-day exclusivity can in certain circumstances be forfeited or be subject to co-exclusivity with other generic applicants.

16. Federal Trade Commission (2002) and Bulow (2003) provide a discussion of the issues involved. 
on the ability of incumbents to pay new entrants. Legislation enacted in December 2003, which contains provisions to discourage agreements that may be anti-competitive while encouraging early patent resolution, may help cure these problems.

More broadly, the strong protection afforded IPRs in the United States is one factor contributing to high domestic branded drug prices and the significantly higher level of health care expenditure in the United States relative to other countries (a focus of the previous Survey). Several aspects of this situation are noteworthy. Drug prices are lower in other member countries largely because of differences in regulations (Vernon, 2002). As a result, US sales are responsible for recovery of a disproportionate share of drug development costs (Danzon, 1997), which are rising rapidly and exceeded $\$ 800$ million (on average, per drug) in recent years, double the levels a decade earlier (Tufts Center for the Study of Drug Development, 2003) ${ }^{17}$ Recent studies have also shown that the return on capital approximately equals the cost of capital in the industry (Grabowski et al., 2002), although earlier studies found excess returns in previous decades, suggesting that more research is needed (Berndt, 2002). The prices paid by US customers vary substantially, with federal government programmes typically facing the lowest prices and individual households paying the highest, although most drug purchases are made by insurers, which negotiate prices with drug companies. This has led to increased efforts, especially among states, to enact programmes that ensure they receive the lowest prices; there have also been proposals to open up the US market to imports from Canada. ${ }^{18}$

Given the set of factors just mentioned, it seems quite likely that successful efforts to lower US drug prices would decrease the supply of new drugs in the long run, as prices are unlikely to rise materially in other countries. Whether this would prove welfare-improving thus depends upon whether the long-run loss from foregone drug development would exceed the gain from increased current consumption of pharmaceuticals or other goods. ${ }^{19}$ Also, studies have suggested substantial gains from new drug development through improved health (e.g. Lichtenberg and Virabhak, 2002) and through lower expenditures on other treatments (e.g. Lichtenberg, 2002). One study (Finkelstein, 2003) has argued that for a few kinds of treatments the dynamic gains from new drug development exceeded the static benefits that would have occurred from treating a greater number of individuals with then-current drugs. But a comprehensive analysis of the potential benefits of increased consumption of current drugs relative to the costs from foregone pharmaceutical development has not been undertaken, probably because such an evaluation would be very difficult. Although it is not conclusively known whether policies that alter investment incentives through changes in government purchasing programmes would have positive or negative long-run effects, the predominant view in the United States is that such effects would be negative.

17. One response to price regulation outside the United States has been the decision of pharmaceutical companies to refuse (or threaten to refuse) to provide products to certain countries such as Canada (Dyer, 2003) and France (Lanjouw, 2003).

18. In particular, the Senate passed a bill on 20 June 2003 that would allow pharmacists to purchase drugs in Canada and resell them in the United States; the House passed a similar provision on 25 July 2003, and such provisions have also been passed in previous years. However, it is not clear that a similar provision, even if it were to become law, would open the US market to parallel imports, as the Secretary of Health and Human Services would need to certify that the drugs imported from Canada were safe and effective; such certification has not been granted in the past.

19. While quantitative evaluations of the tradeoffs associated with lower drug prices are scarce, the presumption made by most academic experts is that such efforts would have negative long-run consequences. For an example of this view, consider Scherer (1993, p. 193): "Should a tradeoff be required between modestly excessive prices and profits versus retarded technical progress, it would be better to err on the side of excessive profits". There is also a distributional issue, as lower drug prices would benefit drug purchasers at the expense of owners of pharmaceutical company shares. 


\section{Regulatory policies and competition}

While the summary approach linking indices of economic policies to macroeconomic outcomes discussed earlier in this chapter can yield some aggregate perspective, the direct — and often large effects of regulatory policies on prices and efficiency within individual markets is both easier to measure and more illustrative when considering how future efforts at regulatory reform may play out. Early views held that regulation increased welfare by offsetting monopoly power; but there is now consensus that regulations often serve to preserve monopoly status, protect inefficiencies in production and impede adjustments to shifting market conditions (e.g. Winston, 1998). As a result, efforts to increase competition in regulated industries through (partial) deregulation or regulatory reform were considerable in both the United States and the rest of the OECD between the mid-1970s and the mid-1990s. The transportation sector (airlines, trucking, intercity buses and railroads) was largely deregulated in the United States by the mid-1980s; banking services were liberalised in the early 1980s, although limitations on interstate banking were lifted only in the late 1990s; and regulations in the natural gas sector have been substantially eased (OECD, 1999).

The effects of liberalisation in these areas have been consistently positive. Operating costs have fallen across the board, and load factors have risen in the transportation sector. Prices for consumers have also dropped significantly - while the quality and range of services offered has tended to increase. Innovations in marketing and product offerings have been substantial. Airlines have developed a broad selection of price/features packages; the introduction of the airline hub-and-spoke system generated an unexpected increase in flight frequency; rail and truck lines have developed price/service combinations to meet customers' production and inventory management plans; and banks have expanded their financial-service offerings, improving risk management opportunities (Winston, 1998). Nonetheless, a number of policy distortions affecting competition in air services remain. The United States has bilateral "open skies" arrangements with a number of European countries, but the largest market (the US-UK market) does not have an agreement, and those currently in place severely limit competition (with restrictions on ownership, market share and landing rights). There are also limits to foreign competition on US domestic routes and to foreign ownership of domestic carriers. There would be substantial benefits to consumers from further liberalisation.

The favourable experiences with deregulation, together with technological advances in both telecommunication services and electricity generation, combined to create pressure for regulatory reform in these sectors over the course of the 1990s. Progress has been made in both cases (Annex 1). But these gains have been accompanied by a number of setbacks, that have highlighted difficulties in ensuring competition in network industries, as well as by some policy mistakes. There is now a solid body of cross-country evidence that liberalisation policies in network industries have led to higher productivity and, in some cases, better quality and lower prices. ${ }^{20}$ However, close attention needs to be paid to the design of reforms (Gonenc et al., 2001).

Before turning to the details of each sector, it is noteworthy that the division of regulatory responsibilities between federal and state agencies is quite similar in both areas. ${ }^{21}$ The institutional

20. See OECD (2001), which thoroughly reviews the literature and adds more evidence on the relationship between regulation and performance in these sectors. The series of OECD Reviews of Regulatory Reform also constitute a rich source of information on the effects of industry-specific reforms on performance.

21. The discussion of telecommunications markets below focuses on the institutional structure in the United States and the extent to which reform measures have contributed to improved performance. While lessons from international experience are a central part of the discussion, relatively little attention is paid to the prices of telecommunication and electricity services in the United States relative to that in other countries. This is appropriate because much of the gain from competitive provision of such services should be expected to accrue to consumers over the long run, as more efficient signals are provided for investment 
structure of regulatory policy has been largely unchanged since before World War II. For telecommunication services, the Federal Communications Commission (FCC) has exclusive jurisdiction over interstate matters and intra-state issues where legislation pre-empts state authority. FCC rules are subject to appeal through the judicial system, which has figured prominently in the FCC's most controversial decisions. Each of the 50 states and the District of Columbia have Public Utility Commissions (PUCs), which generally have jurisdiction over intra-state concerns such as local and within-state long-distance prices and entry into local markets. For electricity markets, the Federal Energy Regulatory Commission (FERC) regulates wholesale electric power sales and the prices charged for transmission services across states, while the state PUCs regulate distribution and retail sales, oversee construction of facilities and determine prices in their local markets. ${ }^{22}$ The joint federal-state system has both costs and benefits: individual state discretion can promote the development of innovative policies, but it can also lead to conflict over priorities and jurisdiction, uncertainty regarding policy direction and increased opportunities for regulatory capture. ${ }^{23}$

\section{Telecommunications}

The telecommunications industry has changed significantly in the last 20 years in response to regulatory reform and, perhaps more importantly, rapid technological progress. ${ }^{24}$ Competition for long-distance voice services entered a new phase in 1984, when, among other things, seven independent Regional Bell Operating Companies (RBOCs) were spun off from AT\&T as part of the settlement of the antitrust case against it. ${ }^{25}$ While AT\&T provided the bulk of long-distance service in 1984 (with a market share of nearly 70 per cent, Figure 5, Panel A), competitive pressures eroded this position, and its market share had fallen to about 33 per cent by 2002. The effects of widespread competition (together with technological change) in long-distance service on prices were readily apparent. Since 1984, real prices for interstate and intra-state long-distance have dropped 64 per cent and 54 per cent, respectively (Panel B), although an indeterminate amount of that drop can be attributed to falling access charges. Relative prices

in new and improved services. Nonetheless, Annex 5.1 presents a comparison of relative prices. US prices are quite low for electricity and below the OECD average for voice services, albeit above those in the lowest-price Member countries. A much earlier study (Blondal and Pilat, 1997) found that the macroeconomic impact of policy changes in these sectors would be quite small as a percentage of GDP, reflecting the prevalence of competitive forces and hence low prices even prior to reform efforts. However, the effect over the long run through incentives for innovation could be larger.

22. FERC also has the ability to approve or disapprove mergers in the electric power industry, oversees the licensing of hydroelectric power projects and regulates interstate natural gas and oil transportation. Contrary to natural gas, the states have transmission siting authority for electricity.

23. More broadly, the intensity of regulatory reform in telecommunications and electricity since the mid-1990s has been accompanied by an apparent increase in the degree of political interference; some have attributed this to the role of political contributions (Hazlett, 2000; The Economist, 2003). The discussion below will focus primarily on economic considerations. As a result, the recent controversy over the FCC's decision to raise the maximum ownership percentage for media outlets is not discussed; this controversy stems from the priority given to diversity and other public interest goals, not from a dispute over economic efficiency.

24. The OECD review of US regulatory policies (OECD, 1999) contains a more detailed treatment of US telecommunications policy developments through 1998.

25. The consent decree required AT\&T to divest its local operating subsidiaries into seven Regional Bell Operating Companies (RBOCs). It separated the country into 164 regions - Local Access and Transport Areas (LATAs), generally smaller than states — and stipulated that RBOCs could not provide services across these regions. RBOCs were forbidden from entering the competitive long-distance (inter-LATA) market to eliminate their incentive to charge discriminatory tariffs for local loop access to companies offering such services. The break-up was accompanied by price caps for AT\&T on long-distance tolls (in effect until 1994) to prevent abuse of its dominant position. 
for local service rose for the first few years following divestiture; this probably reflected a rebalancing of implicit subsidies for local prices from long-distance prices prior to the creation of a competitive long-distance market. It is also apparent from Figure 5 that the fall in AT\&T's market share was quite gradual; AT\&T still held over 65 per cent of the long-distance market in 1990 - six years after its break-up. This moderate pace should provide perspective when considering the spread of local competition.

Figure 5. Market shares and prices in long-distance telephone services
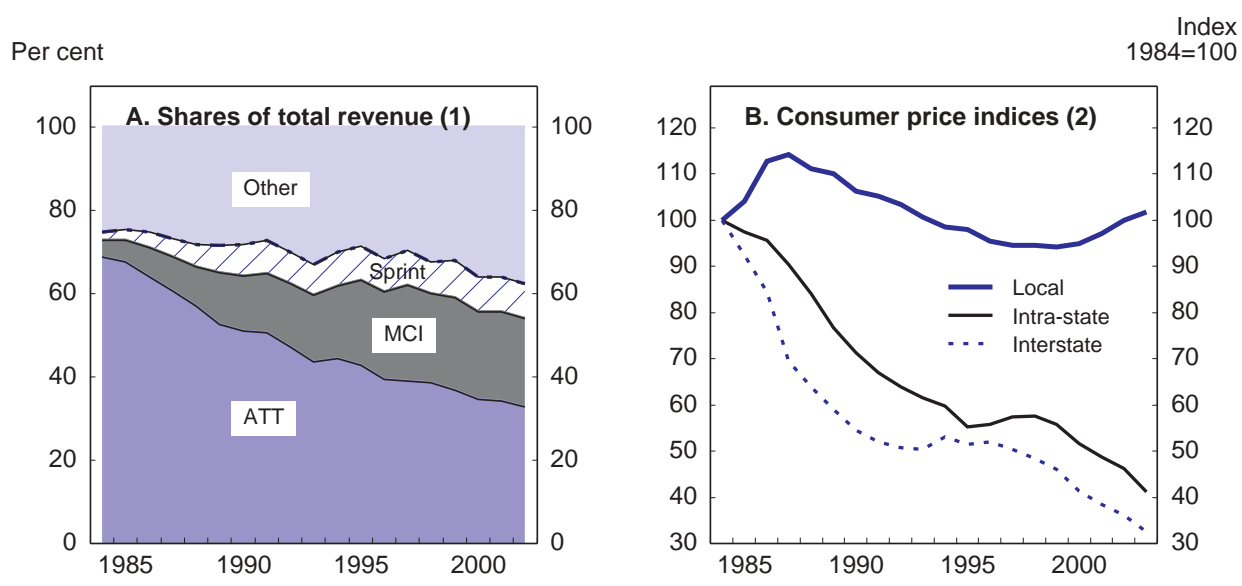

1. Including incumbent local exchange carriers, competitive local exchange carriers and wireless toll service revenues.

2. Relative to all items

Source: Federal Communications Commission and Bureau of Labor Statistics.

The policy changes that accompanied AT\&T's break-up continued to be based on the view that local service was a natural monopoly. However, technological changes and experience with competition in some local areas generated interest in furthering local service competition. ${ }^{26}$ By 1995 , at least 23 states had certified one or more competitors. Competition initially occurred through competitive access providers; these firms provided dedicated access for large business customers to the inter-exchange market, by-passing portions of the local incumbent's exchange network and offering few, if any, local services. Some states, notably New York, also experimented with competition in local services by allowing voluntary unbundling arrangements between local network operators and firms planning to offer local services through licensing of the unbundled network elements — but this never fully blossomed. In particular, there was little incentive for local operators, e.g. RBOCs, to provide unbundled services.

The Telecommunications Act of 1996 began the national effort to spur local service competition. The central idea embedded in the legislation was that competition could be generated with a carrot-and-stick approach. The carrot allowed the Bell operating companies entry into long-distance service outside their local service area and within their region if local service was found to be open to competition. The stick, as implemented in the FCC rules, mandated that incumbent local exchange carriers (including Bell companies) allow requesting carriers to: interconnect to their local networks where feasible with charges based on Total Element Long-Run Incremental Cost (TELRIC); unbundle network elements and provide requesting carriers access to these at TELRIC prices; and resell telecommunications services provided at the retail level to requesting carriers at a wholesale price based on retail prices minus avoidable

26. These technological changes involved innovations that lowered the cost of facilities-based, or alternative network, competition and permitted economical "unbundling" of elements of the local network loop. 
costs. Bell company participation in the long-distance market was aimed at increasing competition there further, and local service competition was desired as a means to lower prices, improve services and, particularly, spur innovation. While these two goals are distinct, the carrot-and-stick approach linked them because of concerns that the technical support from RBOCs necessary for local competition (such as physical modifications to switches, processing of competing carriers' requests for access to network elements and other operational services required to facilitate sharing of the local loop) would not be forthcoming without some incentive for their co-operation; Bell company entry in long-distance services was used as an enticing carrot. In the event, legislation was slow to apply, in part because of court challenges to FCC implementation of the Act.

The development of local-service competition was halting, at best, after 1996. Uncertainty regarding the outcomes of legal challenges was one factor, and through 1998 all five Bell company applications to enter in-region long-distance markets were rejected for lack of open local markets. The first approval came in New York in late 1999. But the situation has now changed, and some degree of local competition has now spread through much of the country. In recent data (mid-2003), at least one competitive local exchange carrier provided local service to customers in zip codes containing 95 per cent of the US population; the median household had seven such carriers in its zip code; 39 per cent had 10 or more. Entry has been greatest in more populated areas (Figure 6); an exception to this is Texas, where competitive carriers have been very aggressive - in part reflecting the early support to local competition from the Texas public utility commission. Bell company applications to provide long-distance services now have been approved in all applicable states and the District of Columbia. While the period over which Bell company competition in long-distance services and substantial entry in local services has occurred is quite short, there is some evidence that prices have fallen (Hausman et al., 2002). ${ }^{27}$ Moreover, the delay of Bell company entry into long-distance services probably came at some cost to consumers (Crandall and Hazlett, 2000), although in recent years wireless, Internet and cable telephony offers have put downward pressure on prices.

Competitive entrants have achieved only modest market shares; 14.7 per cent of local access lines were provided by competitive carriers at mid-2003, seven years after the Telecommunications Act, though their share rose more than 3 percentage points over the previous year and is the second highest for new entrants across OECD countries. The faster penetration of new competitors among large customers where their market share was 23 per cent most recently - indicates that this submarket has responded more quickly to competitive forces, while the small business and residential submarkets, where competitive providers held 12 per cent of lines, has been less affected. Some of this differential probably reflects a lower incentive to switch for small customers, as their local service prices were already low before competition. ${ }^{28}$ In particular, universal service goals had resulted in a severely distorted set of prices for residential and business customers. The 1996 Act aimed to restructure and increase the transparency of the subsidies from business to residential, and from urban to rural, customers in a manner that facilitated competition. (Such changes would be necessary in a purely competitive market to prevent cream-skimming by competitive entrants of business customers paying high regulated rates). However, these changes have been slow to materialise, leading some researchers to conclude that the limited development of competition in local residential services occurred until recently because competitors have had difficulty offering rates below the subsidised rates faced by these customers (Crandall and Waverman, 2000).

27. According to the CPI, the average price of telephone services has continued to fall and is now below the level prevailing in 1997.

28. It is interesting to recall that the cross-subsidies, relative to marginal costs, provided to residential customers by business customers reflect the preservation by regulators of AT\&T's original business strategy. During the initial rollout of telephone service, AT\&T figured that the value of the phone network to a business customer was greater the larger the number of residential customers, and hence it set prices low for residential customers and high for business customers. 
Figure 6. Number of competitive local exchange carriers across the United States

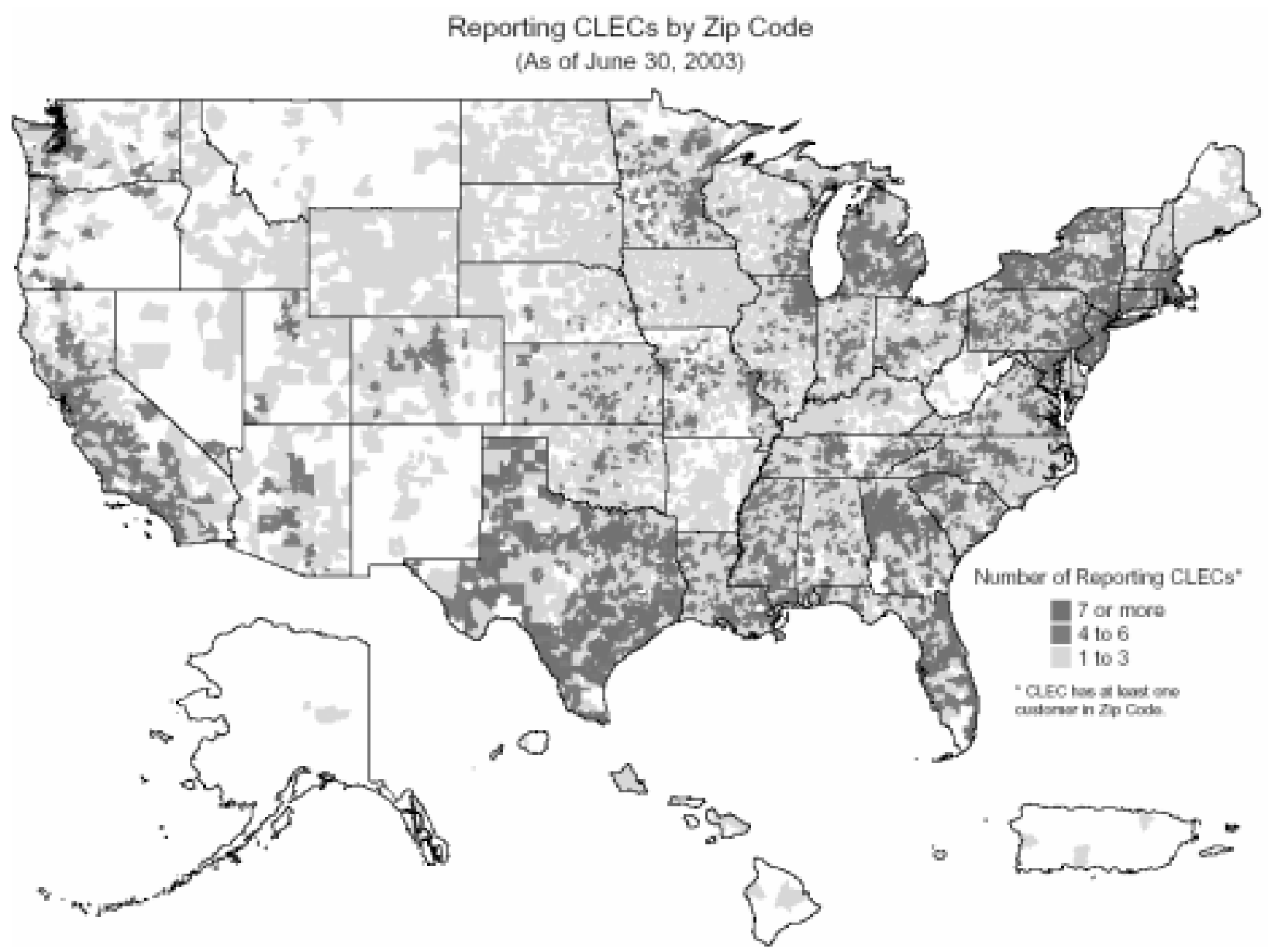

Source: Federal Communications Commission (2003), Local Telephone Competition: Status as of June 30, 2003, Industry Analysis and Technology Division, Wireline Competition Bureau, December.

Government policies were one factor slowing the emergence of local competition...

The data also show that local competition has developed primarily through entrants' use of the incumbents' facilities, either through purchase of unbundled network elements (UNEs) or resale of services purchased at a wholesale discount. At mid-2003, 58 per cent of competitive carriers' lines were based on UNEs and 18 per cent were based on reselling. Critics of UNE prices have focused on several issues. One has been that unbundling of network elements at TELRIC prices would lower incentives for investments in facilities to provide advanced services: incumbents' incentives would be lower if TELRIC prices do not account for the risk associated with new investments, and entrants might wait to invest until after they had the opportunity to develop experience with the successful investments of incumbents through purchase of unbundled elements. ${ }^{29}$ Another concern has been the implementation of TELRIC prices by state regulatory agencies. It has been common for such prices not to distinguish sufficiently between rural and urban areas, despite the cost differences, and UNE prices for similar services have varied widely across states (Crandall and Hazlett, 2000), suggesting an inconsistent application of the methodology. States have also suffered from a lack of guidance from the FCC regarding performance criteria to judge whether an incumbent local exchange carrier (LEC) has provided interconnection and

29. Proponents of this hypothesis include Hausman (1998a), Jorde et al. (2000) and Crandall (2003). 
access to UNEs in a non-discriminatory manner. On the other hand, defenders of TELRIC state that properly implemented TELRIC prices compensate Bell companies for the risk of new investments, and lower UNE prices should boost demand and stimulate entry. ${ }^{30}$

In its February 2003 Triennial Review decision, the FCC amended the guidelines for unbundling network elements partly in response to previous court rulings that found the Commission's earlier unbundling regime too broad. As a result, Bell companies must continue providing wholesale service to their competitors as they have in the past while reviews by state regulators are conducted to see if this should be changed. The key focus of the state reviews will be to determine if competitors need access to Bell company switches in order not to be "impaired" as a competitor, where impairment covers both availability of switching from an alternate source and an economic criterion for whether a competitor can utilise its own switch. The Triennial Review seeks to refine the imposition of unbundling rules to target market segments where third-party alternatives exist on self-deployment by competitors is feasible, while de-regulating those segments where competition is self-sustaining. For example, there is a presumption in the FCC order that there is no impairment to competitors seeking to serve businesses using $\mathrm{T} 1$ lines $^{31}$ or higher. If a state review determines that certain network elements need not be unbundled, then the competitive carriers currently employing these elements have three years to switch to another platform, presumably their own facilities. This set of decisions is intended to spur investment in facilities-based competition, although the outcome of state reviews will be important in determining the incentives facing the industry. While experience with UNEs has been limited to recent years, there has been empirical evidence that unbundling boosts investment (Willig et al., 2002), consistent with the view that competition lowers prices, increases demand and hence generates higher capital requirements. Nevertheless, experience is also consistent with arguments that the UNEs deter investment by reducing ILEC returns from investment and deter CLEC investment by providing free option to use ILEC equipment. A move to eliminate unbundling may not result in investment in facilities in the near term by competitive carriers currently serving a large customer base, given their financial problems.

The Review also amended the rules governing advanced (broadband) services, again in an effort to spur deployment. Previous rules allowed line sharing, under which competitive digital subscriber line (DSL) carriers (a form of high-speed internet connection) buy only the high-frequency portion of a copper loop from an incumbent carrier, when the incumbent already offers voice service over the same line. This unbundling requirement will be phased-out over the next three years; new customers can be added for one year using line sharing. Only one company uses this service, and its phase-out will see the company fall back to purchasing the entire copper loop. The FCC is, however, maintaining its line-splitting rules, which facilitate joint use of an unbundled loop by voice and data competitors. New investments in fibre-to-the-home need not be shared with competitors. Hybrid deployments of fibre/copper wire are subject to lesser unbundling requirements. The relaxation of unbundling requirements on broadband services may affect competition, as it would result in only Bell companies and cable providers offering the service in a local area (as satellite services are currently only a marginal part of the market, as discussed below). However, the authorities point to the potential trade-off between promoting investment and promoting competition. An alternative would have been to preserve unbundling requirements for existing services (while noting that at some point facilities-based competition would be expected to be the standard) and clarify that investment in advanced services (i.e. moving fibre closer to the home) would be exempt from unbundling for some time.

30. This is consistent with the positive impact of competition on investment found for regulated industries more generally in earlier empirical work (Ahn, 2002; Alesina et al., 2003).

31. A T1 line can carry 24 digitalised voice channels or data at a rate of 1544 megabits per second. 


\section{... and will need amendment in response to emerging technologies}

The 1996 Act preserved the view that local fixed-line telephone service was not a close substitute for alternative telecommunications services and hence required a set of regulatory rules to facilitate competition over the local loop. This view is increasingly, but not totally, outdated as a result of new technologies. Mobile phone service is the most direct narrow band competitor; 148 million mobile lines were held at mid-2003 ( 45 per cent of the total). This represented an increase of 85 per cent from the end of 1999 - a period over which the number of total fixed lines fell 6.4 per cent. ${ }^{32}$ It is still the case that the substantial preponderance of mobile phone subscribers also subscribe to fixed-line telephone services. Cable and internet telephony is still limited, but it is growing fast and could further blur the distinction between telecommunications and information services. This emerging competitive fringe will create challenges for the current framework of access charges and fees that fund universal service.

In particular, universal service goals were expanded as part of the 1996 Act. There are currently four government support programmes for: high-cost carriers (which are often in rural areas); low-income households; rural health-care providers; and schools and libraries. These are funded by fees (i.e. taxes) on interstate and international revenues of carriers providing telecommunications services and are difficult to defend on economic efficiency grounds. With regard to the goal of universal service, there is little evidence that the subsidies are of much benefit, as demand for basic local fixed-line telephone service is relatively price-inelastic (e.g. Wolak, 1996; Hausman, 1997, 1998b and 1999). Pursuing legitimate equity goals through cross-subsidisation is very costly. The fees have a high efficiency cost, because interstate and international calling is price-sensitive and priced above marginal cost, implying that any boost to prices from fees yields a large deadweight loss. For example, Hausman (1997) estimates that the efficiency loss for each extra dollar of revenue from fees on interstate and international calls slightly exceeds one dollar; in 2001, universal service fund contributions by carriers were slightly more than $\$ 5$ billion dollars, implying a similar deadweight loss. (Other taxes on services with lower price elasticities, such as income taxes, have efficiency losses that are an order of magnitude smaller). A final problem arises because universal service fees are levied on carriers providing telecommunications services, and technological change has begun to blur the line between telecommunications and information services. For example, internet telephony is not subject to universal service fees because it is deemed an information service; as technological advances make this service more attractive, the current fee structure will make even less economic sense. Access charges create a similar distortion: because internet telephony has been classified as an information service, it pays access charges only to enter the local loop and not for inter-exchange traffic - creating strong incentives to develop services to avoid higher access charges for inter- or intra-state connections for traditional voice services. ${ }^{33}$ Access charge reform should be high on the policy agenda. The FCC is currently seeking comments on the appropriate regulatory treatment of Internet telephony. This inquiry will address the issues raised in the preceding discussion, including the applicability of access charges.

Broadband deployment poses challenges beyond those associated with the development of new voice services. Approximately 16 per cent of the adult population - about 30 million people - had residential broadband connections in March 2003 - a six-fold increase over the level in mid-2000

32. Yet this penetration is still less than in Europe, probably because of the lack of a single technical standard: while most of the world uses the Global System for Mobiles (GSM) technology, US firms are split between a variant of that (GSM/GPRS), Code Division Multiple Access (CDMA) and Integrated Digital Enhanced Network (IDEN).

33. Reports in July 2003 indicated that Worldcom (now renamed MCI) was under investigation for fraud related to (alleged) efforts to re-route calls to avoid access charges. If proven, these allegations would indicate that the current structure of access charges has perverse effects beyond its presumed impact on usage, product offerings and innovation. 
(Pew Internet and American Life Project, 2003). Provision is dominated by cable (67 per cent of lines) and DSL provided by incumbent telephone carriers or other firms using UNEs purchased from incumbents (30 per cent of lines). Cable firms have not been subject to unbundling requirements, and these will be removed for incumbent telephone carriers under the most recent Triennial Review. This asymmetric treatment reflects the legacy of Bell company dominance in local phone service, which has led to the designation of Bell companies as dominant providers for services over their lines and hence subject to extra regulation. In broadband service, the market facts clearly do not support the view that Bell companies are dominant (and more detailed empirical work backs up this claim, e.g. Crandall et al., 2002; Hausman et al., 2001a and 2001b). But, as noted, removal of their unbundling requirements will lead to a duopoly between a cable firm and incumbent telephone carrier in each market, limiting competition further. Although some cable operators voluntarily provide access to independent Internet providers because of service imperatives as well as broader competitive considerations, for the time being it would seem preferable to maintain Bell companies' unbundling requirements and require that cable firms allow open access to independent ISPs. Technological developments may at some point obviate the need for such policies. ${ }^{34}$

\section{Electricity}

Regulatory reform in the electricity sector was driven, in part, by many of the same factors that had influenced efforts in telecommunications: successful liberalisation in many other industries; a new perspective on the technical feasibility of separating transmission and distribution from generation and retailing; technological progress in the form of economically efficient smaller-scale generating plants; and dissatisfaction with the distortions to prices across states and different customers induced by regulation (especially in states with high prices). ${ }^{35}$ Unlike in other areas where the United States has often been a leader in reform, the US experiments followed those in a number of other Member countries, most notably that in the early 1990s in England and Wales. Although the recent blackout in the northeast has highlighted the need for change, the spectacular failure of the California experiment in 2000-01 has chilled enthusiasm for reform throughout the country, and the lessons from this experience are a focus of what follows.

\section{Regulation contributed to wide variation in electricity prices across states}

While regulatory reform should be expected to improve efficiency, it is notable that the US electric power industry performed very well for a long time under the traditional regulated-monopoly model in terms of international standards for productivity, costs, reliability and prices (Joskow, 2003). Problems began to arise in the 1970s, as fossil fuel prices surged. In 1978, the Public Utilities Regulatory Policies Act (PURPA) created a class of qualifying facilities (QFs) including generators using non-fossil fuel and renewable energy sources and co-generators, which supply electricity as a by-product of industrial

34. The regulatory structure, with its relatively inflexible designation of Bell companies as dominant carriers, may face other long-run challenges from technological change. Policy changes to address technological convergence in telecommunications will likely require legislative action, as the distinction between telecommunications and information services was solidified by the 1996 Act. The regulatory framework recently adopted by the European Union may provide some lessons (Marcus, 2002). It emphasizes the need for regulations to exist in situations where market power is significant; in such cases within telecommunications services, this would require dominant firms to provide non-discriminatory access to the network, as well as access to and use of unbundled network elements (UNEs). The key distinction between this framework and that in the United States lies in the presumption in US regulations that incumbent telephone carriers are dominant and hence must face restrictions on their activities. The EU framework can, in principle, adapt to technological convergence through appropriate redefinition of the relevant markets.

35. An accessible introduction can be found in Brennan et al. (2002). The OECD review of US regulatory policies (OECD, 1999) contains a more detailed treatment of US electricity policies through 1998. 
processes. PURPA required utilities to connect QFs to the transmission networks and purchase power from them at avoided costs; these provisions were designed to stimulate investment in generation that was less dependent on fossil fuels and more environmentally friendly. A number of states, particularly California and several in the northeast, embraced this requirement wholeheartedly, sometimes requiring utilities to enter 20- to 30-year contracts with QFs. In addition, these states also turned to nuclear power to a greater extent. Both decisions turned out to be costly (in part because fossil fuel prices retreated in the second half of 1980s and because of technological developments), resulting in much higher regulated retail electricity prices in these regions than elsewhere in the country (Table 3). Retail prices in New York, California and New England have been more than double those in low-cost states in the west and south (such as Idaho, Kentucky, Washington and Wyoming) in recent years.

Table 3. Retail electricity rates

(Cents/KWh)

\begin{tabular}{l|rr|rr|rr|rr}
\hline \multirow{2}{*}{ Census division } & \multicolumn{2}{|c|}{ Residential } & \multicolumn{2}{c|}{ Commercial } & \multicolumn{2}{c|}{ Industrial } & \multicolumn{2}{c}{ All sectors } \\
\cline { 2 - 9 } & \multicolumn{1}{|c|}{2002} & 2001 & 2002 & 2001 & 2002 & 2001 & 2002 & 2001 \\
\hline \multirow{2}{*}{ New England } & 11.1 & 11.6 & 9.5 & 10.1 & 7.9 & 7.7 & 9.9 & 10.2 \\
Mid Atlantic & 10.7 & 10.8 & 9.9 & 9.8 & 5.7 & 5.8 & 9.2 & 9.1 \\
East North Central & 7.6 & 7.7 & 7.2 & 7.0 & 4.7 & 4.6 & 6.4 & 6.3 \\
West North Central & 6.7 & 6.8 & 5.4 & 5.5 & 4.0 & 4.2 & 5.5 & 5.6 \\
South Atlantic & 7.4 & 7.8 & 6.3 & 6.4 & 4.1 & 4.2 & 6.3 & 6.5 \\
East South Central & 6.3 & 6.5 & 6.3 & 6.3 & 3.6 & 3.7 & 5.2 & 5.3 \\
West South Central & 7.6 & 7.6 & 6.8 & 7.1 & 4.4 & 4.5 & 6.2 & 6.4 \\
Mountain & 7.5 & 7.5 & 6.4 & 6.4 & 4.7 & 4.5 & 6.3 & 6.2 \\
Pacific Contiguous & 10.2 & 9.9 & $\mathrm{Nm}$ & 10.6 & 7.1 & 7.4 & 9.9 & 9.5 \\
Pacific Non-contiguous & 14.2 & 13.5 & 12.5 & 12.3 & 10.6 & 10.1 & 12.5 & 12.1 \\
US average & 8.1 & 8.3 & 7.8 & 7.7 & 4.7 & 4.8 & 7.0 & 7.0 \\
\hline
\end{tabular}

Source: Energy Information Administration, Form EIA-826, "Monthly Electric Utility Sales and Revenue Report with State Distributions". Downloaded on 10 June, 2003 from http://www.eia.doe.gov/cneaf/electricity/epm/epmt53p1.html.

A positive side-effect of PURPA was the demonstration that independent generators could supply power to a vertically integrated generation, transmission and distribution system without disruption. This combined with technological change in the form of compact, reliable and relatively low-emission gas turbines to spur interest in developing a competitive generation sector. The 1992 Energy Policy Act (EPAct) established non-utility generators known as exempt wholesale generators (EWGs). These are exempt from PURPA's renewable fuel and cogeneration requirements. Unlike QFs, utilities are not obligated to purchase from EWGs. The EPAct also gave the Federal Energy Regulatory Commission (FERC) the authority to order that utilities provide transmission service to wholesale generators on a reasonable and non-discriminatory basis. ${ }^{36}$ Transmission access to end-users - retail access - was not required by the EPAct; states retained discretion in this matter in their jurisdictions.

36. FERC orders 888 and 889 (issued in 1996) implemented this authority: Order 888 required utilities to open their grids for transmission, expand capacity to accommodate new generating capacity as necessary, and unbundle wholesale power prices into rates for generation, transmission and other services; Order 889 mandated that information on capacity, prices and services for transmission be provided on a common information network (the Open Access Same-time Information System, OASIS). 
The wide variation in electricity rates across states and the emergence of a more competitive wholesale market encouraged a number of states with high prices to pursue reform at the retail level. The motivation was largely the prospect of lower prices; in fact, a component of most retail competition plans was the introduction of a baseline option for consumers involving a mandatory reduction in rates (Joskow, 2003). At the same time, however, many plans froze retail rates for a transition period at levels that were thought to be high enough to allow the utilities to recover "stranded costs" associated with earlier decisions by regulators. Experience has varied by state, but currently restructuring is largely on hold outside the Northeast and Texas, Oregon and Arizona (Figure 7).

\section{The experience of California demonstrates some cautionary lessons}

Two words summarise the reasons behind the drop-off in reform among the states: California and Enron. The meltdown in California's electricity market over the course of 2000-01 dominated headlines and is embedded in the public's mind as the prime example of failed retail competition. ${ }^{37}$ Enron was involved in restructuring in most states that introduced competition, and reports of its misleading actions and bankruptcy have further tainted efforts to move forward. In Enron's case, the long-term damage is probably more one of perception than substance (although its actions may have contributed to some irregularities in California). ${ }^{38}$ California's experience provides more direct instruction on some of the features of electricity markets that make competition so difficult. ${ }^{39}$

The state's experiment with competition in the retail electricity market began in April 1998. Initially, default retail rates charged by the incumbent utilities were set 10 per cent below 1996 levels. The wholesale market performed as expected, at least in terms of prices, through early spring 2000. However, beginning in May, spot prices began to rise dramatically (Figure 8). By this point, the utility in San Diego had recovered its stranded costs and was no longer obligated to charge retail customers the legislated default rates of 10 per cent below 1996 prices; consequently, prices for end-users in its region rose dramatically and were capped by the California legislature (with a commitment to repay the losses to the utility caused by the cap). The other two large utilities were still charging the low regulated retail rates and began incurring large losses. With FERC's approval, wholesale prices were capped at \$250/MWh from August until December 2000. Subsequently, FERC imposed a soft cap of \$150/MWh on wholesale prices; the cap could be breached if suppliers could justify the higher prices based on costs. In any event, high gas and emissions permit prices, as well as complex transactions in which power was first sold to a marketer at a higher price and then resold through the California system operator at those high rates, briefly resulted in wholesale prices in excess of $\$ 400 / \mathrm{MWh} .{ }^{40}$ Given that the regulated retail rates implied sales to end-users at $\$ 65 / \mathrm{MWh}$, the two utilities outside San Diego were losing $\$ 50$ million a day in late December; they had accumulated about $\$ 12$ billion in liabilities for wholesale power charges over the previous twelve months. This burden made it progressively more difficult to finance their operations, and both were approaching insolvency at the end of the year. The lights would have gone out in California in early 2001 had the state not stepped in, first by purchasing power to meet utilities short position in power and then by entering

37. A number of summaries are available, including Brennan et al. (2002), Joskow (2001) and Wolak (2003a). Much of the description of the system and crisis herein follows Joskow (2001).

38. Enron and five other companies were found by FERC to have manipulated the dysfunctional California market, and the state is slated to receive approximately $\$ 2$ billion in refunds (although the exact amount has not been determined). FERC forbade Enron from selling electricity or natural gas in the United States as from 25 June 2003. This ruling is supposed to hold until Enron emerges from bankruptcy.

39. Annex 5.2 provides further details on California's reform plan.

40. On 25 June 2003, FERC demanded that more than 60 sellers, including some of the nation's largest power companies, justify why they should not be forced to give up profits obtained through improper behaviour. 
Figure 7. Status of state electric industry restructuring activity February 2003

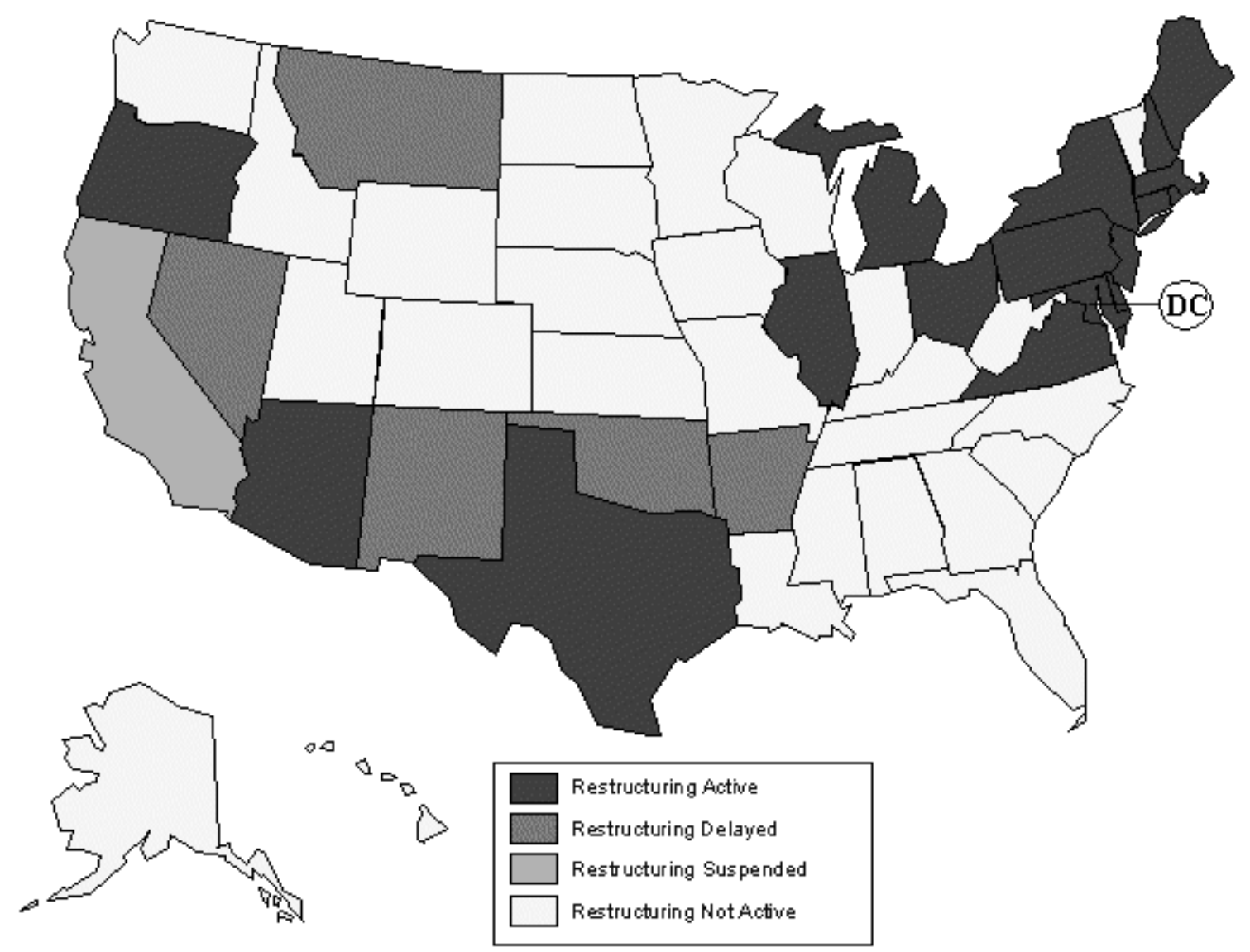

Source: Energy Information Administration, ( http://www.eia.doe.gov/cneaf/electricity/chg_str/regmap.html.)

Figure 8. Average wholesale price of electricity in California, 2000 and 2001

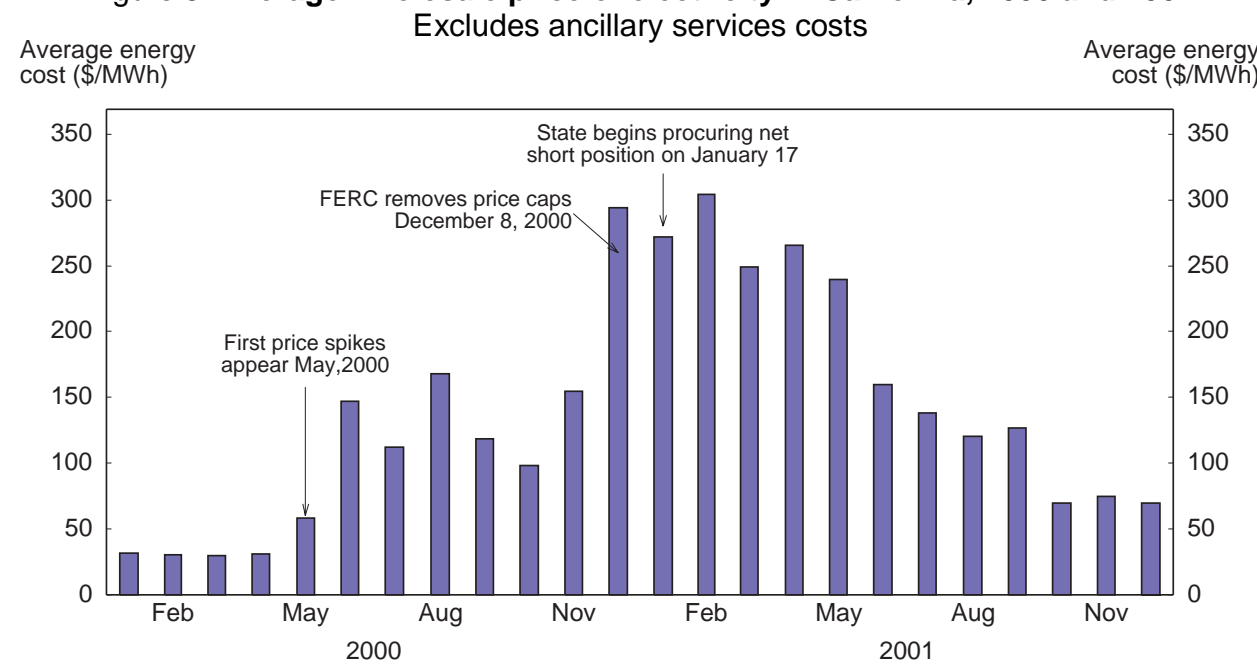

Source: Data from CA ISO (http://www.caiso.com/docs/2001/03/22/2001032214552322811.pdf) and Department of Water Resources Revenue Requirement Draft Filing (October 19, 2001). Downloaded from California Public Utility Commission on June 10, 2003. 
long-term contracts to purchase electricity and acting to raise retail electricity rates by 40 per cent beginning June 2001. The crisis was over by late summer 2001. However, the state of California had entered long-term contracts (typically of about 10 years in duration) to purchase power worth approximately $\$ 45$ billion. The state ended retail choice in September 2001; the experiment had been a dramatic failure.The crisis was caused by the weaknesses in the wholesale and retail market design in California, not by the introduction of competition. That is not to say that prices would not have risen dramatically in 2000-01 even under a well-designed system; indeed, they probably would have. A number of factors contributed. Natural gas prices rose significantly, raising the costs of the marginal generators. Prices of permits for nitrogen oxide emissions also jumped in late 2000, as the number of permits fell (as had been planned for some time, consistent with the desired reduction in emissions). The impetus to higher rates from these was exacerbated by the weather; a heat wave boosted demand for electricity throughout the west, while drought conditions contributed to a drop in the available electricity from outside the state (where hydroelectricity is an important power source). And this boost was on top of a sharp uptrend in electricity demand from the mid-1990s stemming from the rapid pace of growth. The increase in demand had resulted in a relatively tight electricity market in California, as little additional capacity came on line after the mid-1990s in the western states, due in large part to investors' wariness to finance new plants, given uncertainties about the market rules they would face as well as lengthy review processes and opposition from local communities. However, it is probably not correct to conclude, as some have, that failure to approve new power plants was a binding constraint on supply and hence a key factor in the crisis. New supply in the form of QFs came on line in the early 1990s, after which there was a perception of excess supply in the market. The surge in demand led to an awareness that supply had become tighter, and the approval process was a factor that delayed new capacity coming on line until mid-2001; but the natural delays in construction and failure to forecast the surge in demand were also important (Joskow, 2001).

\section{Elsewhere reforms have yielded more mixed results}

Despite the fact that prices would have risen even under an ideal market design, it now appears that the unilateral exercise of market power by power generators was substantial during the crisis (e.g. Borenstein et al., 2002; Joskow and Kahn, 2002; Annex 2). California's crisis has not been the only example where market power has boosted prices after regulatory reforms that have increased the use of markets to determine prices. Such occurrences have been common. Bushnell and Saravia (2002) documented such behaviour in New England and the PJM (portions of Pennsylvania, New Jersey and Maryland, as well as Delaware and Washington, DC), as has Wolfram (1999) in England and Wales. In fact, the Market Surveillance Committee in California repeatedly noted market-power concerns and warned that the lack of price sensitivity of demand and the absence of forward contracting could precipitate a more severe crisis (Wolak et al., 1998 and 1999; Wolak 1999 and 2003b). However, experience outside of California has in general been more favourable. This may reflect, in part, greater use of forward contracts. Demand is more elastic over longer horizons, and forward contracts limit suppliers' gains in revenue from a high spot price, thereby lowering the incentives for marginal generators to withhold power supply. ${ }^{41}$ Outside California, it was common for utilities to be required to enter forward contracts when divesting generation assets (or for divestiture not to be required, in which case a utility would have an implicit forward contract with itself to cover demand from its customers). Another factor has been the adequacy of supply: wholesale electricity markets tend to exhibit low prices during periods of excess supply, and such situations have been more common elsewhere in the United States or abroad than in California - especially in summer 2000, when the drought limited potential imports from hydroelectric sources elsewhere in the west.

41. This is not to say that forward contracting is a panacea: given underlying market conditions of high concentration and difficult entry, forward contracts will be negotiated at higher-than-competitive rates. 
More broadly, the transition to competitive markets in wholesale and/or retail electricity markets has been smoother in other countries such as Australia, England and Wales, New Zealand, Norway and Spain. An important factor has been the institutional differences between the United States and most other countries. Electricity regulation in the United States has largely been a state responsibility, making a national strategy difficult to develop. In addition, the US industry is dominated by privately owned, vertically integrated utilities; while other countries have often started with a plan to separate competitive (e.g. generation and marketing) and natural monopoly (e.g. transmission and distribution) segments and could proceed with such plans because of government ownership, such actions would involve exerting control over private property in the United States. A concomitant constraint on competition is the relative lack of integration in transmission networks across regions (or even states). This derives from the state-by-state nature of regulatory regimes and the lack of need for strong interconnections under the vertically integrated utility model; an unfortunate effect on reform is that the number of competitors within some regions is limited and cannot be increased without investment in transmission capacity. The August 2003 blackout in the north-east showed that the US electricity system has drastic problems. A November 2003 report from a US-Canada task force investigating the blackout found that it was the result of equipment failures, co-ordination problems, violations of reliability standards and human error. The energy bill now being considered in Congress contains provisions to make mandatory compliance with existing voluntary system reliability standards and foster regional transmission integration and related investment. However, it may not address satisfactorily weaknesses in the regulatory framework, which must be fixed to enable a functioning competitive market.

\section{Competition would be facilitated by some policy changes}

The domestic and international experience points to a few changes that could improve efficiency. Reform will need to proceed flexibly because a great deal of disagreement remains regarding how best to manage the transition from a structure that is balkanised across states and dominated by vertically integrated private firms to a more regionally integrated network with separation between competitive and monopoly activities (as emphasized in, for example, Joskow, 2003). One positive step has been FERC's proposal regarding a standard market design (SMD) for wholesale markets. This plan calls for four regional transmission operators (RTOs) to manage transmission across the country. Greater regional integration and uniformity in rules across states would facilitate infrastructure investment, eliminate discriminatory practices by network owners and limit the exercise of market power (through market power mitigation measures such as price caps). Moreover, multi-state entities for planning, certification, and siting at a regional level should improve oversight of transmission investment, as such bodies are better placed to consider the regional externalities of new capacity than state commissions. Increased regional integration could result in substantial net savings to consumers after deducting SMD implementation costs (US Department of Energy, 2003).

As noted above, the spread of retail competition has stalled since the California debacle. Proponents of a continuation of reforms to encourage retail competition need to acknowledge that the short-run benefits in terms of lower prices will be limited in the low-rate states that have not begun restructuring; rather, the gains will accrue over the long run, as retail competition fosters increased use of "innovations" like demand management policies and, in conjunction with wholesale competition, provides superior signals for investments in generation and transmission capacity. Retail competition programmes could learn from the experiences of England and Wales, Texas and California. They should ensure (at least functional) separation of competitive and monopoly activities. Given the slow rate at which customers switch service providers, reform should also make full deregulation of the incumbent's retail prices wait until a competitive market has time to develop. The default service price should vary, perhaps slowly, with the wholesale rate. And customers who switch to competitive retailers should not be allowed to switch back to the regulated default service if competitive prices rise; only by creating a customer base that can be relied upon over a medium- to long-run horizon will retailers have sufficient incentives to enter forward 
contracts for their demand. The US experience has demonstrated that the gains from retail competition for residential and small business customers are not significant in the short run, and hence it may also be best to move forward with retail choice for larger customers first as the EU has done, as such customers can gain much more from value-added services for demand management.

\section{Concluding remarks}

In summary, as a result of reform efforts over the past two decades or so, competitive forces have been stronger in the United States than in most other OECD countries. Nonetheless, there is scope for improvements in a number of areas. Some recommendations concerning competition law, international trade, intellectual property rights and major network industries are provided in Box $\mathbf{1}$. These seem to be the most important issues regarding product market competition. As noted, however, others might need attention, notably the tort liability system and public procurement. Annex 3 provides some information on tort reform, which could enhance the proper functioning of markets and thus productivity and employment in a number of sectors, and Annex 4 deals with public procurement where the injection of competitive elements has been limited, especially at the state level.

\section{Box 1. Recommendations regarding product market competition}

\section{Competition law and policy}

The competition law combines unusually severe penalties for horizontal collusion with a complex, economically-motivated approach to monopoly and other restraints. Some remaining problems are consequences of this approach and of the roles and capacities of courts, local governments and private litigants.

- $\quad$ To sustain the success of the leniency programme in cartel enforcement, strong sanctions should be maintained against hard-core conduct, but provisions for private damages and other recoveries should be modified in order to preserve the incentive to be the first conspirator to come forward.

- $\quad$ Some anomalous exemptions and special regimes have found their way into US law, often to undo enforcement actions, sometimes in conjunction with regulatory programmes. These anomalous exemptions should be eliminated to improve coherence and to promote competition. The antitrust immunity of government enterprises should be terminated: no other Member exempts government-related firms from competition enforcement. Other anomalies are the exemption of many non-profit entities from the jurisdiction of the FTC and also include the remaining exemptions in the otherwise liberalised trucking industry to the treatment of insurance under the McCarran-Ferguson Act.

- The state action doctrine risks embarrassing the national commitment to competition. The OECD's regulatory reform review called for a systematic study of the doctrine's economic effects as a prelude to substantial reform. This still has not been done. State-law constraints on competition should be removed.

- The complexity and cost of litigation may result in under-enforcement of rules about non-per se conduct; on the other hand the incentive of treble damages may encourage too much litigation over it. Clear principles for deciding about non-criminal restraints should be developed and endorsed by the courts.

\section{Trade barriers}

The US economy is relatively open to foreign competition, resulting in higher consumer welfare, and the United States is committed to pursue trade liberalisation. Nonetheless, additional efforts would be desirable.

- Heavy-handed customs procedures and threatened (or levied) anti-dumping and countervailing duties cannot be justified economically, leading to higher prices for consumers and impeding necessary adjustments. Hence, policy initiatives that lower reliance on anti-dumping, countervailing and safeguard actions and similar protectionist measures should be pursued.

- Despite the relative openness of the US economy and a positive set of government proposals, US leadership to successfully conclude the Doha round is needed. Care should also be taken that multilateral liberalisation is not undermined by bilateral agreements.

\section{Intellectual property rights}

- Intellectual property rights create special challenges for competition, as their purpose is to limit competition in the short-run in order to capture the long-run benefits of dynamic competition through innovation. While a broad set of specific 


\section{Box 1. Recommendations regarding product market competition (cont'd)}

recommendations must wait until after the ongoing study within the OECD on IPRs, innovation and economic performance, a few reforms would clearly be welfare-enhancing.

- An opposition system for patents similar to that in Europe (giving broader rights for grants to be challenged) should be considered. This would help improve the quality of the patent review process and limit the costs of subsequent litigation.

- The standards for non-obviousness and quality of patents should be raised, in particular in emerging technology fields. Limited reverse-engineering of software should be allowed to facilitate interoperability.

- Hatch-Waxman agreements that stop entry by generic drug firms through payments from branded drug firms should be illegal, although other types of settlements that facilitate resolution of patent disputes without payments from branded to generic firms would (of course) remain legal. Generic firms that abandon efforts to enter should lose their exclusive 180-day right to produce.

\section{Telecommunications regulation}

While local service competition has begun to take root, some recent policy changes have moved in the wrong direction, and new initiatives are needed to increase competition.

- Unbundling of network elements has boosted competition for local voice services and provided incentives for investment in new services; mandatory unbundling should be continued for the foreseeable future.

- The FCC should develop national performance and impairment standards to help state regulatory commissions assess whether incumbents have met their unbundling obligations.

- With a view to aiding broadband deployment, unbundling requirements for incumbent telephone carriers should be maintained, and cable firms should be required to open their lines using older technology to independent internet service providers.

- The current form of universal service fees may be distortionary. It would be better to lower or eliminate universal service subsidies and/or, when deemed necessary, to fund such subsidies from less distorting broad-based taxes.

- Access charges based on jurisdictional (i.e. local, intrastate but not local, interstate) lines will be challenged by technological changes and create incentives to innovate around existing regulations rather than efficiently. Reviewing the inter-carrier compensation regime, including reduction of access charges, should be high on the policy agenda.

\section{Electricity regulation}

California's experiment provides an example of how reform can fail. Hence, future efforts should proceed cautiously. With that caveat, a number of policy changes could improve efficiency through increased competition.

- Electricity markets have developed on a state-by-state or small region basis. Efforts to increase regional integration should be considered. The Standard Market Design (SMD) initiative of the FERC is one example.

- The balkanised ownership of transmission assets, the potential for local market power and difficulties in pricing congestion over the network make it unlikely that competitive forces will spur efficient investment in transmission capacity - so-called "merchant transmission investment" (Joskow and Tirole, 2003). The costs and benefits of such investment relative to a regulated monopoly transmission company (as in England and Wales) need study, as do the legal issues associated with divestiture of transmission assets and potential reforms.

- The SMD appropriately includes market power mitigation measures, such as price caps, to limit the extent to which generators can set prices above marginal cost. But such measures will also lower incentives to invest in new capacity. While there is currently excess capacity in much of the country, measures to support investment in generation through requirements that distributors contract for peak demand plus some reserve margin may be necessary. 1

- Further efforts to promote retail competition should proceed first with large customers. Default service programmes should not mandate price reductions, and limits on high-frequency customer switching should be included, so that retailers have incentives to enter forward contracts.

- While many issues discussed in the OECD's Regulatory Reform in the United States (1999) have not been repeated to conserve space, its recommendations still need attention. In particular, distortions to competition through tax and subsidy systems should be removed (e.g. the differential tax treatment of public utilities). Privatisation of government-owned assets (including small public utilities and large federal entities like the Tennessee Valley Authority and the power marketing authorities) should be considered.

1. California and Texas did not impose such a requirement, while the New England ISO did. 


\section{BIBLIOGRAPHY}

Abel, J. (2002),

"Entry into Regulated Monopoly Markets: The Development of a Competitive Fringe in the Local Telephone Industry", Journal of Law and Economics, Vol. 45, 289-316.

Ahn, S. (2002),

"Competition, Innovation and Productivity Growth: A Review of Theory and Evidence", OECD Economics Department Working Papers, No. 317.

Alesina, A. et al. (2003),

"Regulation and Investment", NBER Working Papers, No. 9560.

Anand, B. and T. Khanna (2000),

"The Structure of Licensing Contracts", Journal of Industrial Economics, Vol. 48, No. 1, 103-135.

Arora, A. and A. Fosfuri (2000),

"The Market for Technology in the Chemical industry: Causes and Consequences", Revue d'Economie Industrielle, Vol. 92, 317-34.

Arundel, A. (2001),

"Patents in the Knowledge-Based Economy", Beleidstudies Technology Economie, Vol. 37, 67-88.

Baker, D. (1996),

"The High Cost of Protectionism: The Case of Intellectual Property Claims", Economic Policy Institute Technical Working Paper No. 230.

Barton, J. (2000),

"Reforming the Patent System", Science, Vol. 287, 1933-1934.

Barton, J. (2001),

"Non-Obviousness", mimeo, Stanford University Law School.

Berndt, E. (2002),

"Pharmaceuticals in U.S. Health Care: Determinants of Quantity and Price", Journal of Economic Perspectives, Vol. 16, No. 4, 45-66.

Blanchard, O. and F. Giavazzi (2002),

"Macroeconomic Effects of Regulation and Deregulation in Goods and Labor Markets", Quarterly Journal of Economics, Vol. 118, No. 3.

Blondal, S. and D. Pilat (1997),

"The Economic Benefits of Regulatory Reform", OECD Economic Studies, No. 28, 7-48. 


\section{ECO/WKP(2004)21}

Borenstein, S. (2002),

"The Trouble with Electricity Markets: Understanding California's Restructuring Disaster", Journal of Economic Perspectives Vol. 16, No. 1, 191-211.

Borenstein, S. et al. (2002),

"Measuring Market Inefficiencies in California's Restructured Wholesale Electricity Market", American Economic Review, Vol. 92, No. 5, 1376-1405.

Bradford, S. (2003),

"Paying the Price: Final Goods Protection in OECD Countries", Review of Economics and Statistics, Vol. 85, No. 1, 24-37.

Brennan, T. et al. (2002),

Alternating Currents: Electricity Markets and Public Policy, RFF Press, Washington, D.C.

Bulow, J. (2003),

'The Gaming of Pharmaceutical Patents", mimeo, Stanford Business School.

Bushnell, J. and C. Saravia (2002),

"An Empirical Assessment of the Competitiveness of the New England Electricity Market", Center for the Study of Energy Markets (CSEM) Working Papers, No. 101.

Campbell, T.J. et al. (1995),

"The Causes and Effects of Liability Reform: Some Empirical Evidence", NBER Working Papers, No. 4989.

Campbell, T.J. et al. (1995),

"The Link Between Liability Reform and Productivity: Some Empirical Evidence", Brookings

Papers on Economic Activity: Microeconomics, 107-148.

Coggburn, J.D. (2003),

"Exploring Differences in the American States' Procurement Practices", Journal of Public

Procurement, Vol. 3, No. 1, 3-28.

Cohen, W. et al. (2000),

"Protecting Their Intellectual Assets: Appropriability Conditions and Why U.S. Manufacturing

Firms Patent (or Not)?”, NBER Working Papers, No. 7552.

Congressional Budget Office (2003),

The Economics of US Tort Liability: A Primer, Washington, D.C., October.

Congressional Budget Office (2004),

Limiting Tort Liability for Medical Malpractice, January.

Council of Economic Advisers (2002),

"Who Pays for Tort Liability Claims? An Economic Analysis of the US Tort Liability System", April.

Crandall, R. (2003),

"Debating U.S. Broadband Policy: An Economic Perspective", Policy Brief, No. 117, The Brookings Institution. 
Crandall, R. and T. Hazlett (2000),

"Telecommunications Policy Reform in the United States and Canada", AEI-Brookings Joint Center for Regulatory Studies Working Papers, No. 00-9.

Crandall, R. and L. Waverman (2000),

Who Pays for Universal Service? When Telephone Subsidies Become Transparent, Brookings

Institution Press, Washington, DC.

Crandall, R. et al. (2002),

"The Empirical Case Against the Asymmetric Regulation of Broadband Internet Access", Berkeley Technology Law Journal, Vol. 17, No. 3, 953-987.

Danzon, P.M. (1997),

"Price Discrimination for Pharmaceuticals: Welfare Effects in the U.S. and the E.U." International Journal of the Economics of Business, Vol. 4, No. 3, 301-321.

Danzon, P.M. and M.F. Furukawa (2003),

"Prices and Availability of Pharmaceuticals: Evidence from Nine Countries", Health Affairs, October.

Dyer, G. (2003),

"Astra Zeneca in limits on Canada", The Financial Times, 23 April.

Federal Trade Commission (2002),

"Generic Entry Prior to Patent Expiration: An FTC Study".

Feldstein, M. (2003),

"Why is Productivity Growing Faster?", NBER Working Paper No. 9530.

Finkelstein, A. (2003),

"Health Policy and Technological Change: Evidence from the Vaccine Industry", NBER Working Papers, No. 9460.

Gallaway, M. et al. (1999),

"Welfare Costs of US Anti-dumping and Countervailing Duties Laws", Journal of International Economic, Vol. 49, 211-244.

Gallini, N. (2002),

"The Economics of Patents: Lessons from Recent U.S. Patent Reform", Journal of Economic Perspectives, Vol. 16, No. 2, 131-154.

Gallini, N. and S. Scotchmer (2001),

"Intellectual Property: When Is It the Best Incentive System?", Innovation Policy and the Economy, Vol. 2, 51-77.

Gilbert, R. and W. Tom (2001),

"Is Innovation King at the Antitrust Agencies? The Intellectual Property Guidelines Five Years Later", Antitrust Law Journal, Vol. 69, No. 1, 43-86.

Gonenc, R. et al. (2001),

"The Implementation and the Effects of Regulatory Reform: Past Experience and Current Issues", OECD Economic Studies, No. 32, 183-227, Paris. 
Grabowski, H. et al. (2002),

"Returns on R\&D for 1990s New Drug Introductions", mimeo, Duke University, Department of Economics.

Graham, J. et al. (2003),

"Post-issue Patent 'Quality Control': A Comparative Study of U.S. Patent Re-examinations and European Patent Oppositions", forthcoming in Cohen, W. (ed.), Intellectual Property in the Knowledge-Based Economy, Washington, DC, National Academies Press.

Gust, C. and J. Marquez (2002),

"International Comparisons of Productivity Growth: The Role of Information Technology and Regulatory Practices", International Finance Discussion Papers 727, Board of Governors of the Federal Reserve System.

Hall, B. (2003),

"Business Method Patents, Innovation, and Policy”, NBER Working Papers, No. 9717.

Hall, B. et al. (2003),

"Prospects for Improving U.S. Patent Quality Via Post-Grant Opposition", NBER Working Papers, No. 9731.

Hall, B. and R. Ziedonis (2001),

"The Patent Paradox Revisited: An Empirical Study of Patenting in the U.S. Semiconductor Industry, 1979-1995", Rand Journal of Economics, Vol. 32, 101-128.

Hausman, J. (1997),

"Valuation and the Effect of Regulation on New Services in Telecommunications", Brookings

Papers on Economic Activity, Microeconomics.

Hausman, J. (1998a),

"The Effect of Sunk Costs in Telecommunications Regulation", mimeo, Massachusetts Institute of Technology, October.

Hausman, J. (1998b),

"Taxation Through Telecommunications Regulation", Tax Policy and the Economy.

Hausman, J. (1999),

"Efficiency Effects on the U.S. Economy from Wireless Taxation", mimeo, Massachusetts Institute of Technology, July.

Hausman, J. et al. (2001a),

"Cable Modems and DSL: Broadband Internet Access for Residential Customers", American

Economic Review, Vol. 91, No. 2, 302-307.

Hausman, J. et al. (2001b),

"Residential Demand for Broadband Telecommunications and Consumer Access to Unaffiliated Internet Content Providers", Yale Journal on Regulation, Vol. 18, No. 1, 129-173.

Hausman, J. et al. (2002),

"Does Bell Company Entry into Long-Distance Telecommunications Benefit Consumers?", Antitrust Law Journal, Vol. 70, 463-484. 
Hazlett, T. (2000),

"Economic and Political Consequences of the 1996 Telecommunications Act", Regulation, Vol. 23, No. 3, 36-45.

Huber, P. (1988),

Liability: The Legal Revolution and Its Consequences, Basic Book, New York.

Irwin, D. (2003),

"Causing Problems? The WTO Review of Causation and Injury Attribution in U.S. Section 201

Cases", NBER Working Papers, No. 9815.

Jaffe, A. (2000),

"The US Patent System in Transition: Policy Innovation and the Innovation Process", Research Policy Vol. 29, No. 4-5, 531-557.

Janis, M. (1997),

"Rethinking Re-examination: Toward a Viable Administrative Revocation System for U.S. Patent Law", Harvard Journal of Law and Technology, Vol. 11, No. 1, 1-122.

Jorde, T. et al. (2000), "Innovation, Investment and Unbundling", Yale Journal on Regulation, Vol. 17, No. 1, 1-37.

Joskow, P. (2001),

“California's Electricity Crisis", Oxford Review of Economic Policy, Vol. 17, No. 3, 365-388.

Joskow, P. (2003),

"The Difficult Transition to Competitive Electricity Markets in the United States", mimeo, Massachusetts Institute of Technology.

Joskow, P. and E. Kahn (2002),

"A Quantitative Analysis of Pricing Behavior in California's Wholesale Electricity Market During Summer 2000", The Energy Journal, Vol. 23, No. 4, 1-35.

Joskow, P. and J. Tirole (2003),

"Merchant Transmission Investment", NBER Working Paper, No. 9534.

Kessler, D.P. and M. McClellan (1996),

“Do Doctors Practice Defensive Medicine?", Quarterly Journal of Economics, Vol. 111, 353-390.

Knetter, M. (1994),

"Why are Retail Prices in Japan So High? Evidence from German Export Prices", NBER Working Papers, No. 4894.

Kortum, S. and J. Lerner (1998),

"Stronger Protection or Technological Revolution: What is Behind the Recent Surge in Patenting?", Carnegie-Rochester Conference Series on Public Policy, Vol. 48, 247-304.

Kremer, M. (2001), "Creating Markets for New Vaccines - Part I: Rationale; Part II: Design Issues", Innovation Policy and the Economy. Vol. 1, 35-118. 
Kruger, L. and A. Gilroy (2001),

"Broadband Internet Access: Background and Issues", CRS Issue Brieffor Congress, Congressional Research Service, The Library of Congress, 17 April.

Lanjouw, J. (2002a), "Intellectual Property and the Availability of Pharmaceuticals in Poor Countries", forthcoming in Innovation Policy and the Economy, Vol. 3.

Lanjouw, J. (2002b),

"A Patent Proposal for Global Diseases: U.S. and International Legal Issues", forthcoming in Harvard Journal of Law \& Technology.

Lehman, D. and D. Weisman (2001),

The Telecommunications Act of 1996: The "Costs" of Managed Competition, Kluwer Academic Publishers, Boston.

Lerner, J. (1994),

"The Importance of Patent Scope: An Empirical Analysis", RAND Journal of Economics, Vol. 25, No. 2, 319-333.

Lerner, J. (1995),

"Patenting in the Shadow of Competitors", Journal of Law and Economics, Vol. 38, No. 2, 463-496.

Lerner, J. (2002),

"Patent Policy Reform and Its Implications", NBER Reporter, Winter 2002/2003, 17-19.

Levin, R. and J. Levin (2002),

"Patent Oppositions", mimeo, Yale University and Stanford University.

Lichtenberg, F. (2002),

"Benefits and Costs of Newer Drugs: An Update", NBER Working Papers, No. 8996.

Lichtenberg, F. and S. Virabhak (2002),

"Pharmaceutical-Embodied Technical Progress, Longevity, and Quality of Life: Drugs As

‘Equipment For Your Health’”, NBER Working Papers, No. 9351.

Lundsgaard, J. (2002),

"Competition and Efficiency in Publicly-Funded Services", OECD Economics Department Working Papers, No. 331.

Marcus, J. (2002),

"The Potential Relevance to the United States of the European Union's Newly Adopted Regulatory Framework for Telecommunications", OPP Working Paper Series, No. 36, Office of Plans and Policy, Federal Communications Commission.

National Association of States Purchasing Officials (1997), State and Local Government Purchasing: Principles \& Practices, Lexington, NY.

Nicoletti, G. and S. Scarpetta (2003),

"Regulation, Productivity and Growth: OECD Evidence", OECD Economics Department Working Paper, No. 347. 
OECD (1999),

Regulatory Reform in the United States, Paris.

$\operatorname{OECD}(2003)$,

The Sources of Economic Growth in OECD Countries, Paris.

Pew Internet and American Life Project (2003),

"Adoption of Broadband to the Home", May.

Scherer, F.M. (1993),

"Pricing, Profits, and Technological Progress in the Pharmaceutical Industry", Journal of Economic Perspectives, Summer.

Shapiro, C. (2001),

"Navigating the Patent Thicket: Cross Licenses, Patent Pools, and Standard Setting", Innovation Policy and the Economy, Vol. 1.

Swagel, P. (1995),

"Import Prices and the Competing Goods Effect", International Finance Discussion Papers, No. 508, Federal Reserve Board.

Sykes, A. (2003),

"The Safeguards Mess: A Critique of WTO Jurisprudence", University of Chicago Law School, mimeo.

Tarullo, D. (2003), "Paved With Good Intentions: The Dynamic Effect of WTO Review of Anti-dumping Action", Georgetown University Law Center, mimeo.

The Economist (2003),

"America's Regulatory Mess", 24 July.

Tufts Center for the Study of Drug Development (2003),

"Outlook 2003", Tufts University.

US Department of Energy (2003),

"Report to Congress: Impact of the Federal Energy Regulatory Commission's Proposal for Standard Market Design", 30 April.

US General Accounting Office (1999),

"District of Columbia Authority Needs to Improve Its Procurement Practices", GAO/GGD-99-134, August.

US Office of Management and Budget (2001),

The President's Management Agenda.

Vernon, J. (2002),

"Drug Research and Price Controls", Regulation, Winter 2002-2003, 22-23.

Viscusi, W.K. (1984),

"Structuring an Effective Occupational Disease Policy: Victim Compensation and Risk Regulation", Yale Journal on Regulation, 53-81. 
Wegner, H. (2001),

"Invalidity Defenses to E-patent Infringement: A Comparative View of the Differing Ways to Achieve Patent Justice in the United States", Paper presented at the SOFTIC 2001 Symposium, Tokyo, Japan.

Willig, R. et al. (2002),

"Stimulating Investment and the Telecommunications Act of 1996", mimeo, Princeton University.

Winston, C. (1998),

"U.S. Industry Adjustment to Economic Deregulation", Journal of Economic Perspectives, Vol. 12, No. 3, 89-110.

Wolak, F. (1996),

"Can Universal Service Survive in a Competitive Telecommunications Environment? Evidence from the United States Consumer Expenditure Survey", February, available at http://www.stanford.edu/ wolak.

Wolak, F. (1999),

"A Report on the Redesign of California's Real-time Energy and Ancillary Services Markets", October 18, available at http://www.stanford.edu/ wolak.

Wolak, F. (2000),

"An Empirical Analysis of the Impact of Hedge Contracts on Bidding Behavior in a Competitive Electricity Market", International Economic Journal, Vol. 14, No. 2, 1-40.

Wolak, F. (2003a),

"Lessons from the California Electricity Crisis", Center for the Study of Energy Markets (CSEM) Working Papers, No. 110.

Wolak, F. (2003b), "Measuring Unilateral Market Power in Wholesale Electricity Markets: The California Market 1998 to 2000", American Economic Review, Vol. 93, No. 2, 425-430, May.

Wolak, F. et al. (1998),

"Preliminary Report on the Operation of the Ancillary Services Markets of the California Independent System Operator (ISO)", August 19, available at http://www.stanford.edu/ wolak.

Wolak, F. et al. (1999),

"Report on the Redesign of the Markets for Ancillary Services and Real-time Energy", March 25, available at http://www.stanford.edu/ wolak.

Wolfram, C. (1999),

"Measuring Duopoly Power in the British Electricity Spot Market", American Economic Review, Vol. 89, No. 4, 805-826. 


\section{PRICES FOR VOICE AND ELECTRICITY SERVICES}

The analysis of telecommunication and electricity services in the main text focuses on the challenges facing competitive provision in each market and possible policy responses. Moreover, it is emphasised that price reductions for all customers may not be the result of competition, especially in electricity; rather, reform is likely to result in a rebalancing of relative prices (for example, between lowand high-cost electricity states, or between telecommunications and information services following access charge reform). This should facilitate efficient investment and development of advanced services. A comparison with other Member countries reveals that prices for residential and business voice services in the United States lie somewhat below the OECD average but well above those in the lowest-price countries; electricity rates are low in comparison to those in most Member countries.

Figure A1. OECD composite basket of residential telephone charges ${ }^{1}$ November 2003

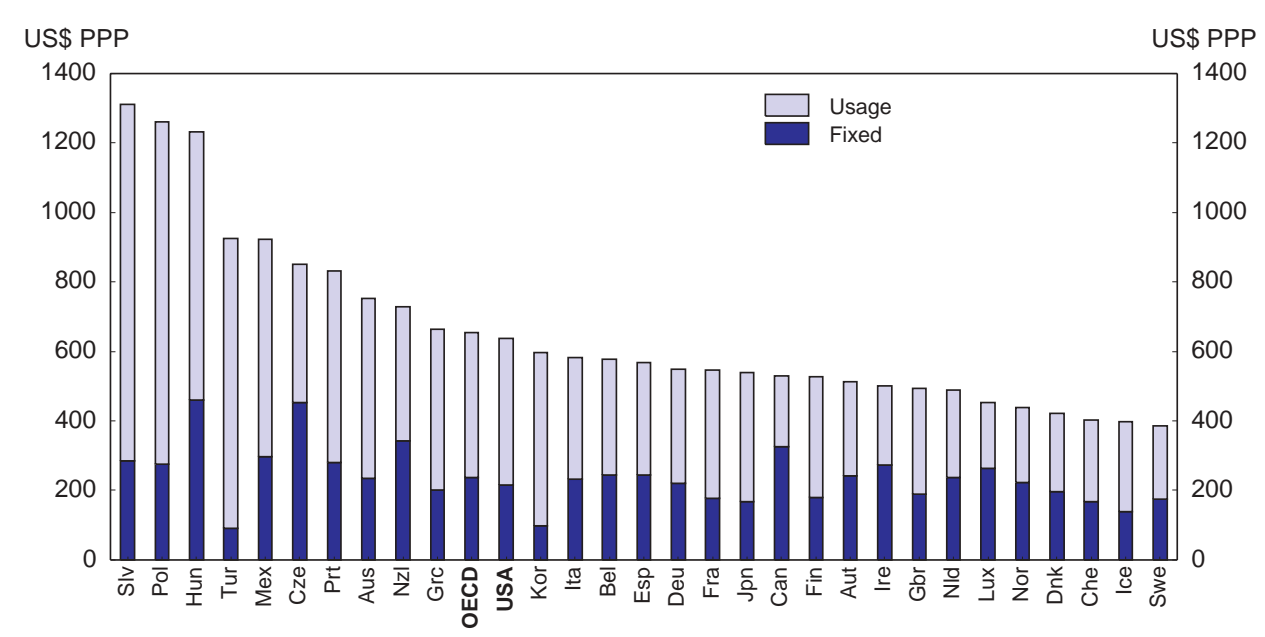

1. Composite basket includes international calls and calls to mobile networks. Source: OECD. 
Figure A2. OECD composite basket of business telephone charges ${ }^{1}$ Excluding VAT, November 2003

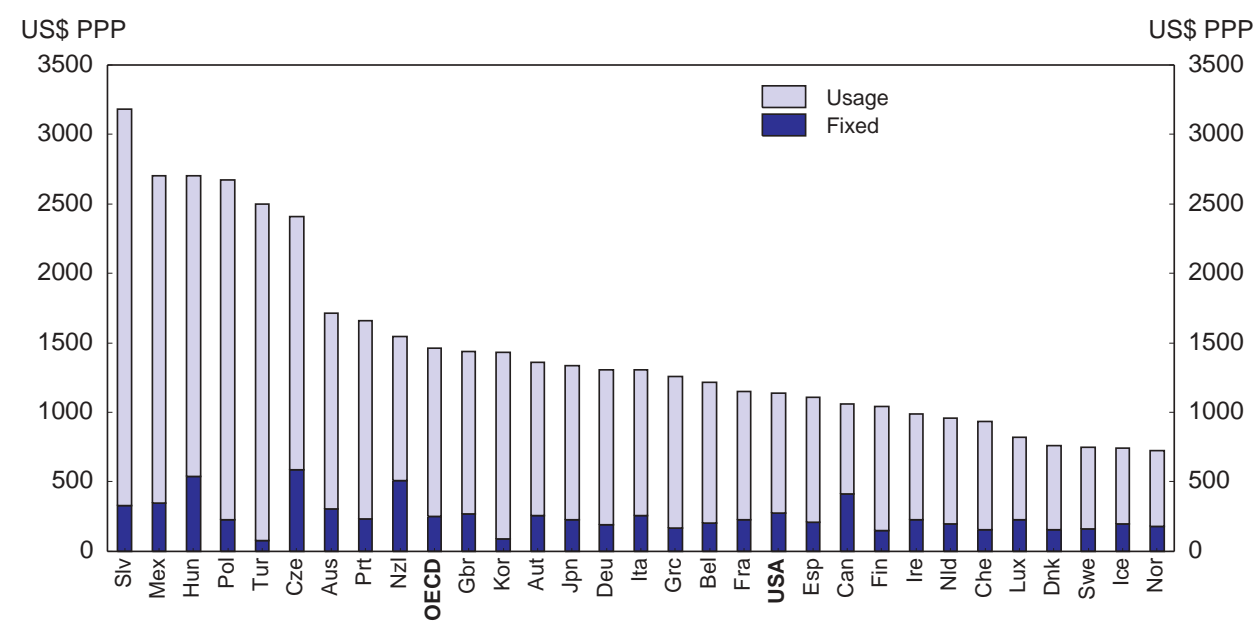

1. Composite basket includes international calls and calls to mobile networks. Source: OECD.

Figure A3. Electricity prices for households US $\$ / K W h$ converted with PPP 2002 or latest available year ${ }^{1}$

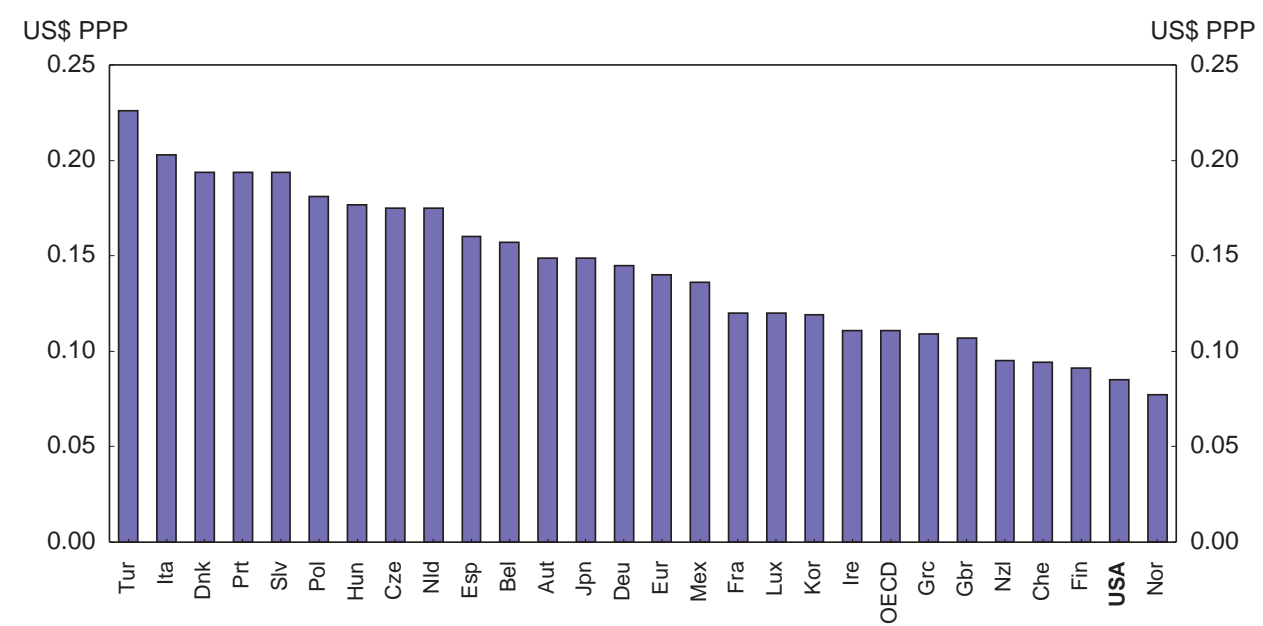

1. 2000 for Germany and Spain; 2000 for Belgium. Source: International Energy Agency. 
ECO/WKP(2004)21

\section{ANNEX 2}

\section{CALIFORNIA'S EXPERIENCE WITH REFORM OF RETAIL ELECTRICITY MARKETS}

Prior to 1996, California's electricity industry was organized around three private vertically integrated monopolies: Pacific Gas and Electric (PG\&E), Southern California Edison (SCE) and San Diego Gas and Electric (SDG\&E). Their prices, costs and service obligations were heavily regulated by the state commission. In addition, these firms depended on purchasing significant amounts of power in the wholesale market in the western states, Canada and Mexico. In 1996, the state legislature passed a plan to restructure the industry. Its key components were retail customer choice through competitive entry of electricity service providers (ESPs); open access to transmission and distribution networks of the large incumbent utilities; an immediate 10 per cent reduction in retail rates from prevailing regulated prices; creation of an independent system operator (CAISO) to manage the transmission network and a power exchange (CALPX) to run a wholesale market; a requirement that the large utilities meet their default service obligations by purchasing power for those customers through the day-ahead and real-time spot market; and divestiture of at least 50 per cent of PG\&E and SCE's fossil-fuel generating capacity.

Several weaknesses in California's design contributed to the subsequent crisis. The programme was too focused on the near-term drop in prices, and the mandated 10 per cent reduction in rates from 1996 levels was a mistake. The low wholesale prices in the mid-1990s reflected excess supply, and the mandatory price reduction both impeded the spread of retail competition (as entrants to retailing had to beat the lower rates) and completely insulated end-users from wholesale prices. This ensured that demand was extremely inelastic and came on top of the fact that demand is already very inelastic in the short run for most customers, because only very large consumers have real-time meters that provide price information. The inelasticity of demand, in conjunction with the physical properties of electricity, provided considerable scope for the unilateral exercise of market power: because electricity cannot be stored and demand and supply must balance in order to ensure reliability of the network, a supplier in tight market conditions can face a marginal revenue curve that is sharply decreasing in the quantity supplied, making withholding of supply very attractive (e.g. Borenstein, 2002). Importantly, this can occur even when a market has a large number of potential suppliers, so that simple metrics gauging competitive forces by market shares (which have been used by FERC, for example, in assessing market power) can be misleading. A number of studies have concluded that the exercise of market power was substantial during the crisis (e.g. Borenstein et al., 2002; Joskow and Kahn, 2002). The incentives to charge prices substantially above marginal cost was further enhanced by the extensive reliance on the real-time and day-ahead spot markets for wholesale power: a supplier who realized that it could bid its power to the market at a high price would, if successful, sell all its power at the high spot price, as the largest purchasers of wholesale electricity were not allowed to enter into forward contracts hedging this risk. Although the utilities could have hedged this risk, they chose not to, perhaps because the stranded cost recovery programme guaranteed the utilities recovery through the difference between the retail rates they received and the spot wholesale price, not a price they received through a forward contract (Wolak, 2003a). The drop in prices in June 2001 - when most long-term contracts that the state entered became effective suggests the importance of this factor. The imposition of price caps in the spot wholesale market across the west in late June by FERC may have also contributed, although by that point only a fraction of California's power needs were met through the spot market. 


\section{ANNEX 3}

\section{TORT REFORM}

Markets require an efficient and transparent judicial system to function properly. The US institutional framework is by and large appropriate, but there are two exceptions: torts and, less clearly, bankruptcy. Both have been the object of substantial reform efforts in the Congress in recent years. ${ }^{1}$

Changes in the tort liability system have been particularly hotly debated in recent years, especially with regard to medical malpractice claims. The policy discussion has been driven by concerns that the current system has high costs and arbitrary distributive effects and creates a great deal of ex ante uncertainty regarding the risks facing both consumers and firms. Reform proposals have built on earlier efforts at the state level, including limits on punitive damages and even economic damages, caps on attorneys' fees and liability reform. ${ }^{2}$ The latter two categories are designed to lower the costs of administering the system (in part by decreasing incentives to pursue marginal cases), while the former has been suggested as a means to lessen the arbitrary nature of certain rewards. This arbitrariness is evidenced through unusually high rewards in some cases, but also through no rewards or even failure to bring cases by some harmed individuals who are in weakened circumstances.

The system is estimated to have cost $\$ 180$ billion, or 1.8 per cent of GDP, to operate in 2000; this level is double that of other industrialised nations and nearly triple that 30 years earlier (as a per cent of GDP) (Council of Economic Advisers, 2002). ${ }^{3}$ Moreover, a substantial fraction of this expenditure is probably wasteful. Only 46 per cent of funds represent payments to claimants, with the remainder consisting of attorneys' fees and administrative costs. The cost of administering the system is clearly excessive relative to regulatory or government insurance programmes. For example, overhead in the workers' compensation system is only 20 per cent of its funds. While fault and identification of the responsible parties may be particularly easy in such cases, the 54 per cent of funds dissipated in tort actions should be reined in. In addition, tort actions may not be very efficient in those areas where they are

1. Bankruptcy overhaul legislation that would tighten access to personal bankruptcy under Chapter 7 of the federal bankruptcy code by imposing a means test was passed by the House in March 2003. But it never progressed in the Senate because of a threat to amend it so as to prevent abortion protesters from filing for bankruptcy to escape civil fines and judgements. Some observers have also complained about the unfairness of Chapter 11 under which firms can gain cost advantages and then cut prices; a prime example is commercial aviation. As regards tort reform there have been three separate efforts, and all have stalled. First, a bill to establish a $\$ 108$ billion fund to pay asbestos claims according to medical criteria has not yet been brought to the floor after Committee passage in July 2003; no legislation has yet been introduced in the House. Second, once again the House passed legislation to cap non-economic damages for pain and suffering and punitive damages in medical malpractice lawsuits in March 2003, but a similar bill has gone nowhere in the Senate. Finally, a bill to reform class-action lawsuits by making it easier to transfer them from state to federal courts passed the House in June 2003, but a Senate motion for cloture failed in October.

2. A current proposal, passed by the House, would place a cap not only on punitive damages but also on non-economic damages.

3. A more recent figure practiced by the private consultancy Tillinghast-Towers Perrin in December 2003 put the cost at $\$ 233$ billion (2⿺辶/4 per cent of GDP) in 2002, up 13 per cent on the year. 
common, such as medical malpractice and toxic waste. In both cases, determination of causation and liability can be complicated and technically demanding; these requirements may be better met through ex ante regulations by qualified experts (Viscusi, 1984; Huber, 1988). In this regard, most proposals for tort reform are lacking, in that they fail to address the fundamental weaknesses of the tort system that prevent agents from exercising due care and stop injured individuals from receiving just compensation. Proposals include strengthening regulation of product safety, setting up trust funds to avoid class action suits, and allowing parties to avoid the tort system through contractual arrangements. This could be justified if there were clear evidence that the system has resulted in excessive compensation (on average) and therefore less-than-optimal supply, rather than simply being inefficient at providing compensation.

Reform would have several positive effects. Cutting administrative costs by half would lower the implicit tax on economic activity by $1 / 2$ per cent of GDP. Previous studies have demonstrated that the current system encourages doctors to practice defensive medicine and hence increases the cost of healthcare, without improving health; for example, Kessler and McClellan (1996) found that earlier reforms lowered medical expenditures by 5 to 9 per cent with no adverse effects. More recent studies (such as Congressional Budget Office, 2004) found somewhat smaller effects. Research has documented negative effects of the present system, and positive effects of reforms that reduce potential liabilities, on productivity and employment in a broad range of industries (Campbell et al., 1995 and 1998). 


\section{ANNEX 4}

\section{PUBLIC PROCUREMENT}

Competitive sourcing of publicly provided services has been a high priority since the mid-1990s, and the current Administration's management agenda has pushed even harder to bring the discipline of competition to services provided by the federal government. Nearly half of federal employees perform tasks available in the commercial marketplace, and competition between public and private parties has often resulted in cost savings of 20 to 50 per cent for such functions (US Office of Management and Budget, 2001). But the extent of competition has been limited; as a result, the Administration announced changes to the federal government's competitive sourcing programmes last spring. ${ }^{1}$ These changes simplify the definition of activities that are "inherently" governmental and streamline the administrative process associated with conducting competitive bidding. While previous procedures could take as long as four years, the revised guidelines limit the process to one year. These are positive steps. However, the cost savings realised from earlier instances may not be representative of future efficiency gains, as experience remains limited; moreover, international experience suggests that savings have clustered between 10 and 30 per cent (Lundsgaard, 2002).

Introducing competition to primary and secondary education remains a challenge. As discussed extensively in the previous Survey, the No Child Left Behind Act introduced a number of accountability measures designed to increase parental awareness of school quality and to allow choice among public schools to those whose children attend institutions of low quality. Unfortunately, one response at the state level — where standards are set - has been to lower the threshold for low-quality schools, thereby limiting choice. (This reaction may stem, in part, from funding problems; the federal mandate to facilitate choice for those in failing schools was not accompanied by additional funding, and states have been struggling to balance their budgets). Vouchers or other financial assistance to spur greater competition and choice between public and private schools have not spread widely. One positive development in this area was the recent Supreme Court decision which determined that voucher programmes such as that in Cleveland, which are used to attend church-affiliated schools (as well as others, although in some areas most private schools have a religious affiliation), are constitutional.

Procurement policies at the state level have not shifted toward competitive provision to the same extent as those at the federal level. A majority of states have introduced reforms to allow agencies to enter cooperative purchasing agreements, to make purchases based on criteria involving quality and price and to gain greater independent authority based on past cost-savings or quality improvements (Coggburn, 2003). But a systematic account of reforms or efforts to delineate inherently governmental functions as at the federal level is lacking (National Association of State Purchasing Officials, 1997). ${ }^{2}$

1. The Office of Management and Budget issued a revised Circular No. A-76, which governs federal policy for competition of commercial activities, on 29 May 2003.

2. Although it is clear that certain state or local government practices have fallen short of standards for transparency and accountability in their procurement policies (e.g. US General Accounting Office, 1999). 


\section{WORKING PAPERS}

The full series of Economics Department Working Papers can be consulted at www.oecd.org/eco/Working_Papers/

397. Saving Behaviour and the Effectiveness of Fiscal Policy (July 2004) Luiz de Mello, Per Mathis Kongsrud and Robert Price

396. The impact of exchange rate regimes on real exchange rates in South America, 1990-2002 (June 2004) Anne-Laure Baldi and Nanno Mulder

395. How Market Imperfections and Trade Barriers Shape Specialisation: South America vs. OECD (June 2004) Joaquim Oliveira Martins and Tristan Price

394. Housing Markets, Wealth and the Business Cycle (June 2004) Pietro Catte, Nathalie Girouard, Robert Price and Christophe André

393. Long-Term Budgetary Implications of Tax-Favoured Retirement Saving Plans (June 2004) Pablo Antolin, Alain de Serres and Christine de la Maisonneuve

392. Enhancing Income Convergence in Central Europe after EU Accession (June 2004) Patrick Lenain and Lukasz Rawdanowicz

391. Asset Price Cycles, “One-Off” Factors and Structural Budget Balances (June 2004) Nathalie Girouard and Robert Price

390. Channels for Narrowing the US Current Account Deficit and Implications for Other Economies (May 2004) Anne-Marie Brook, Franck Sédillot and Patrice Ollivaud

389. Product Market Competition and Economic Performance in Norway (May 2004) Jens Høj and Michael Wise

388. Product Market Competition and Economic Performance in Sweden (May 2004) Deborah Roseveare, Martin Jørgensen and Lennart Goranson

387. Product Market Competition and Economic Performance in Japan (May 2004) Jens Høj and Michael Wise

386. Migration and Integration of Immigrants in Denmark (May 2004) Deborah Roseveare and Martin Jørgensen

385. Factors Driving Risk Premia (April 2004) Torsten Sløk and Mike Kennedy

384. Rationalising Public Expenditure in the Slovak Republic (March 2004) Rauf Gönenç and Peter Walkenhorst

383. Product Market Competition and Economic Performance in Switzerland (March 2004) Claude Giorno, Miguel Jimenez and Philippe Gugler

383. Concurrence sur les Marchés de Produits et Performance Économique en Suisse (Mars 2004) Claude Giorno, Miguel Jimenez and Philippe Gugler

382. Differences in Resilience between the Euro-Area and US Economies (March 2004) Aaron Drew, Mike Kennedy and Torsten Sløk 


\section{ECO/WKP(2004)21}

381. Product Market Competition and Economic Performance in Hungary

(March 2004) Carl Gjersem, Philip Hemmings and Andreas Reindl

380. Enhancing the Effectiveness of Public Spending: Experience in OECD Countries

(February 2004) Isabelle Joumard, Per Mathis Kongsrud, Young-Sook Nam and Robert Price

379. Is there a Change in the Trade-Off between Output and Inflation at Low or Stable Inflation Rates?

Some Evidence in the Case of Japan

(February 2004) Annabelle Mourougane and Hideyuki Ibaragi

378. Policies bearing on product market competition and growth in Europe

(January 2004) Carl Gjersem

377. Reforming the Public Expenditure System in Korea

(December 2003) Young-Sook Nam and Randall Jones

376. Female Labour Force Participation: Past Trends and Main Determinants in OECD Countries (December 2003) Florence Jaumotte

375. Fiscal Relations Across Government Levels

(December 2003) Isabelle Joumard and Per Mathis Kongsrud

374. Health-Care Systems: Lessons from the Reform Experience

(December 2003) Elizabeth Docteur and Howard Oxley

373. Non-Tariff Measures Affecting EU Exports: Evidence from a Complaints-Inventory (December 2003) Peter Walkenhorst and Barbara Fliess

372. The OECD Medium-Term Reference Scenario: Economic Outlook No. 74 (November 2003) Peter Downes, Aaron Drew and Patrice Ollivaud

371. Coping with Ageing: A Dynamic Approach to Quantify the Impact of Alternative Policy Options on Future Labour Supply in OECD Countries

(November 2003) Jean-Marc Burniaux, Romain Duval and Florence Jaumotte

370. The Retirement Effects of Old-Age Pension and Early Retirement Schemes in OECD Countries (November 2003) Romain Duval

369. Policies for an Ageing Society: Recent Measures and Areas for Further Reform

(November 2003) Bernard Casey, Howard Oxley, Edward Whitehouse, Pablo Antolin, Romain Duval, Willi Leibfritz

368. Financial Market Integration in the Euro Area (October 2003) Carl Gjersem

367. Recent and Prospective Trends in Real Long-Term Interest Rates: Fiscal Policy and Other Drivers (September 2003) Anne-Marie Brook

366. Consolidating Germany's finances: Issues in public sector spending reform (September 2003) Eckhard Wurzel

365. Corporate Taxation of Foreign Direct Investment Income 1991-2001 (August 20030) Kwang-Yeol Yoo

364. Indicator Models of Real GDP Growth in Selected OECD Countries (July 2003) Franck Sédillot and Nigel Pain 